\title{
The ethnobotany of psychoactive plant use: a phylogenetic perspective
}

\author{
Nashmiah Aid Alrashedy ${ }^{1}$, Jeanmaire Molina ${ }^{\text {Corresp. } 1}$ \\ ${ }^{1}$ Department of Biology, Long Island University, Brooklyn, New York, United States \\ Corresponding Author: Jeanmaire Molina \\ Email address: jeanmaire.molina@liu.edu
}

Psychoactive plants contain chemicals that presumably evolved as allelochemicals but target certain neuronal receptors when consumed by humans, altering perception, emotion and cognition. These plants have been used since ancient times as medicines and in the context of religious rituals for their various psychoactive effects (e.g., as hallucinogens, stimulants, sedatives). The ubiquity of psychoactive plants in various cultures motivates investigation of the commonalities among these plants, in which a phylogenetic framework may be insightful. A phylogeny of culturally diverse psychoactive plant taxa was constructed with their psychotropic effects and affected neurotransmitter systems mapped on the phylogeny. The phylogenetic distribution shows multiple evolutionary origins of psychoactive families. The plant families Myristicaceae (e.g. nutmeg), Papaveraceae (opium poppy), Cactaceae (peyote), Convolvulaceae (morning glory), Solanaceae (tobacco), Lamiaceae (mints), Apocynaceae (dogbane) have a disproportionate number of psychoactive genera with various indigenous groups using geographically disparate members of these plant families for the same psychoactive effect, an example of cultural convergence. Pharmacological traits related to hallucinogenic and sedative potential are phylogenetically conserved within families. Unrelated families that exert similar psychoactive effects also modulate similar neurotransmitter systems (i.e. mechanistic convergence). However, pharmacological mechanisms for stimulant effects were varied even within families suggesting that stimulant chemicals may be more evolutionarily labile than those associated with hallucinogenic and sedative effects. Chemically similar psychoactive chemicals may also exist in phylogenetically unrelated lineages, suggesting convergent evolution or differential gene regulation of a common metabolic pathway. Our study has shown that phylogenetic analysis of traditionally used psychoactive plants suggests multiple ethnobotanical origins and widespread human dependence on these plants, motivating pharmacological investigation into their potential as modern therapeutics for various neurological disorders. 


\section{The ethnobotany of psychoactive plant use: a phylogenetic perspective}

2

3 Nashmiah Alrashedy and Jeanmaire Molina*

4 Department of Biology, Long Island University-Brooklyn, 1 University Plaza, Brooklyn, NY, 5 USA 11201

$7 \quad *$ corresponding author: jeanmaire.molina@liu.edu

\section{Abstract}

Psychoactive plants contain chemicals that presumably evolved as allelochemicals but

11 target certain neuronal receptors when consumed by humans, altering perception, emotion and cognition. These plants have been used since ancient times as medicines and in the context of religious rituals for their various psychoactive effects (e.g., as hallucinogens, stimulants, sedatives). The ubiquity of psychoactive plants in various cultures motivates investigation of the commonalities among these plants, in which a phylogenetic framework may be insightful. A phylogeny of culturally diverse psychoactive plant taxa was constructed with their psychotropic

17 effects and affected neurotransmitter systems mapped on the phylogeny. The phylogenetic distribution shows multiple evolutionary origins of psychoactive families. The plant families

21 disproportionate number of psychoactive genera with various indigenous groups using

22 geographically disparate members of these plant families for the same psychoactive effect, an

23 example of cultural convergence. Pharmacological traits related to hallucinogenic and sedative 
24 potential are phylogenetically conserved within families. Unrelated families that exert similar

25 psychoactive effects also modulate similar neurotransmitter systems (i.e. mechanistic

26 convergence). However, pharmacological mechanisms for stimulant effects were varied even

27 within families suggesting that stimulant chemicals may be more evolutionarily labile than those

28 associated with hallucinogenic and sedative effects. Chemically similar psychoactive chemicals

29 may also exist in phylogenetically unrelated lineages, suggesting convergent evolution or

30 differential gene regulation of a common metabolic pathway. Our study has shown that

31 phylogenetic analysis of traditionally used psychoactive plants suggests multiple ethnobotanical

32 origins and widespread human dependence on these plants, motivating pharmacological

33 investigation into their potential as modern therapeutics for various neurological disorders.

35 Keywords: drug discovery, ethnopharmacology, evolutionary ethnobiology, neuropsychopharmacology, psychotropic, traditional medicine

\section{Introduction}

Plants constantly evolve to produce various defensive secondary metabolites against their equally adaptive predators (Polya, 2003; Wink, 2003; Wink, 2016). Some well-known

psychoactive compounds such as atropine, caffeine, cocaine, nicotine and morphine are believed to have been products of this evolutionary arms race (Howe \& Jander, 2008; Fürstenberg-Hägg, Zagrobelny, \& Bak, 2013). Psychoactive, alternatively psychotropic, substances act on the nervous system affecting mental processes and behavior (Spinella, 2001; Rätsch, 2005). They include hallucinogens that distort reality, sedatives/narcotics that induce sleep, calmative or anxiolytics, antidepressants, and stimulants that wake the mind (Spinella, 2001; Rätsch, 2005; 
47 van Wyk \& Wink, 2014). Interestingly, humans have exploited alternate uses for plants

48 containing psychoactive phytochemicals that have purportedly evolved to ward off plant

49 predators. However, the affinity of these phytochemicals within the hominid nervous system may

50 also indicate some kind of mutualistic co-evolution, with ancient humans seeking and perhaps

51 cultivating plant psychotropics to facilitate survival, by alleviating starvation, fatigue and pain

52 (Sullivan \& Hagen, 2002).

Psychoactive compounds have specific molecular targets in the nervous system, and

54 interact in a particular way with neuronal receptors to produce various psychoactive effects

55 (Spinella, 2001; Polya, 2003). For instance, morphine in opium poppy (Papaver somniferum,

56 Papaveraceae) eliminates pain by binding to opioid receptors (Polya, 2003), but simultaneously

57 promotes sedation and euphoria, by disinhibiting dopamine-containing neurons in the limbic

58 system (Johnson \& North, 1992). Dopamine is ultimately responsible for feelings of elation and

59 satisfaction, which occur after some rewarding act like sex or food satiety. Addiction arises from

60 wanting to re-experience the pleasure due to the drug's ability to cause dopamine buildup

61 (Lüscher and Ungless, 2006). Compounds that mimic serotonin and act as receptor agonists like

62 mescaline in the peyote cactus (Lophophora williamsii, Cactaceae), trigger hallucinations and

63 cognitive breakdown (Polya, 2003). Stimulating substances, such as the alkaloid nicotine in

64 tobacco, Nicotiana tabacum (Solanaceae), mimic the endogenous neurotransmitter acetylcholine

65 stimulating muscle contractions and cholinergic areas of the brain involved in arousal and

66 attention (Polya, 2003). And yet, the confamilial Atropa belladonna, contains a chemically

67 different alkaloid, atropine, which promotes sedation and incapacitation via its action as

68 muscarinic acetylcholine antagonist, blocking neuromuscular communication (Spinella, 2001). 
It is well established that all cultures, ancient or modern, have some kind of drug culture,

70 relying on psychoactives for recreational, ritual and/or medicinal uses (Schultes, 1976; Schultes,

71 Hofmann \& Rätsch, 2001; Rätsch, 2005). Shamanistic religions have existed in the Old World

72 of Europe, Asia and Africa, believing that psychoactive plants are capable of healing through

73 divine power. Marijuana (Cannabis spp., Cannabaceae) and opium poppy are among the most

74 popular psychoactive plants used by Old World shamans. Marijuana was used in ancient China

75 for various afflictions like malaria and constipation, and even as a narcotic in surgeries. In India,

76 the plant was considered sacred promoting pleasurable sensations in the user (Clarke \& Merlin,

77 2013). Tetrahydrocannabinol (THC) in marijuana, exerts these actions by binding to cannabinoid

78 receptors, mediating sensory pleasure (Mahler, Smith \& Berridge, 2007). Another familiar

79 psychoactive, opium poppy was used for medicinal and recreational purposes. It probably

80 originated in the Mediterranean, but widespread use has confounded its evolutionary origin

81 (Merlin, 2003). It was recorded in the Eber papyrus, an ancient Egyptian scroll, that opium

82 poppy was used to stop the excessive crying of children (Vetulani, 2001). The plant contains

83 morphine and codeine that are responsible for its hypnotic and analgesic properties (Heinrich et 84 al., 2012).

Indigenous people of the New World have also used psychotropic substances, including

86 tobacco, ayahuasca, and coca, even more so than cultures of the Old World (Schultes, 1976).

87 Tobacco from the leaves of $N$. tabacum has long been used in the Americas, with cultivation in

88 pre-Columbian Mexico or Peru (Rätsch, 2005). American Indians believed in the medicinal

89 power of tobacco, and it was smoked in ceremonial peace pipes to seal covenants. In the Amazon

90 Basin of South America, the hallucinogenic beverage, ayahuasca, is made by healers from the

91 boiled crushed stems of the caapi, Banisteropsis caapi (Malpighiaceae), along with the leaves of 
92 chacruna, Psychotria viridis (Rubiaceae). Chacruna contains serotonergic N,N-

93 dimethyltryptamine (DMT), that is activated by the beta-carbolines in caapi (McKenna, 1996). In

94 the Andes, indigenous peoples chew coca leaves of Erythroxylum coca (Erythroxylaceae) to

95 cope with hard labor, removing symptoms of fatigue and hunger (Nigg \& Seigler, 2013). Its

96 cocaine content prevents dopamine reuptake producing increased energy and mood elevation

97 (Spinella, 2001).

The ubiquity of psychoactive plants in various cultures motivates investigation of the

99 commonalities among these plants, in which a phylogenetic framework may be insightful.

100 Information is assigned to nodes of the phylogeny, instead of one species at a time, facilitating

101 the study of trait distributions (Saslis-Lagoudakis et al., 2015). Phylogenetic studies of culturally

102 diverse medicinal plants have repeatedly shown that medicinal uses and phytochemical traits are

103 not randomly distributed on the phylogeny, but are shared by closely related plants, regardless of

104 these plants' cultural and geographic designations (Saslis-Lagoudakis et al., 2012; Saslis-

105 Lagoudakis et al., 2015; Xavier \& Molina, 2016). In this study we aimed to understand if there is

106 a similar pattern of cultural convergence (Xavier \& Molina, 2016) in psychoactive plants using

107 phylogenetic analysis - does the phylogeny of culturally important psychoactive plants reveal a

108 preference for certain plant families and for specific psychoactive effects (hallucinogenic,

109 sedative, stimulant, etc.)? Additionally, we sought to understand if there is also a pattern of

110 mechanistic convergence, such that unrelated plants with similar psychoactive effects ultimately

111 affect similar neurotransmitter systems. Our study provides insight into the ethnobotanical

112 origins of psychoactive plant use and suggests new plant sources of psychopharmacological

113 drugs.

114 


\section{Materials and Methods}

116 Pyschoactive taxa of seed plants (126 genera) used by various indigenous groups were

117 compiled for this study (Table 1), but plants with psychoactive uses only after alcoholic

118 fermentation were excluded (e.g., wine from grapes, Vitis vinifera). Congeneric species were

119 only represented once in the phylogeny, e.g., Datura spp. included D. discolor Bernh., D. ferox

120 L., D. innoxia Mill., D. metel L., D. stramonium L., D. wrightii Regel. This is to account for

121 taxonomic uncertainties that are common in species circumscriptions, and also not to visually

122 bias the phylogeny towards a certain family with multi-species genera (e.g., Datura). The plants'

123 names were verified in the Plant List (2013), a working list of all known plant species that is

124 maintained by the Royal Botanic Gardens and the Missouri Botanical Garden. The psychoactive

125 uses of each plant were categorized as follows: hallucinogen, sedative (=narcotic/hynotic),

126 stimulant, anxiolytic (=relaxant), and antidepressant. As psychotropic plants may also exert

127 analgesia and/or aphrodisiac effects, these effects were determined for each plant in addition to

128 their original psychoactive use. Multiple effects based on literature were not uncommon. Thus,

129 plants were assigned multiple psychoactive attributes, if applicable. For congeneric taxa, uses for

130 each species were all noted.

131 The 126 psychoactive plant taxa were categorized according to the ethnic groups they

132 were associated with: Native American (including North, Central and South America, 49

133 genera), European (15), Temperate Asian (including China, Russia, 10), Middle Eastern and

134 African (19), Indomalayan (including India and Southeast Asia, 10), Australasia (including

135 Australia, New Guinea, New Zealand, Pacific Islands, 4). Taxa with traditional psychoactive

136 uses in at least two of these groups were designated multi-cultural (19). The uses of the plants

137 were based on the originating indigenous cultures. For example, harmal, Peganum harmala 
138 (Nitrariaceae), is native in the Mediterranean (Europe), but it was used as a stimulant in the

139 Middle East and in Africa, so harmal was assigned to the latter. Guava, Psidium guajava

140 (Myrtaceae), is native to tropical America, but was only used as psychoactive in Africa (Rätsch,

141 2005). Argyreia nervosa (=A. speciosa), though of Indian origin, is considered multi-cultural

142 here. It has been used in Ayurvedic medicine as an analgesic and aphrodisiac (Galani, Patel \&

143 Patel, 2010), but Hawaiians (Australasia) have been using it as alternative to marijuana (Rätsch,

144 2005). Cultural designations for each plant were all noted, with overlapping origins, if

145 applicable, indicated.

146 To construct the phylogeny, the sequence of $r b c L$ (the gene that codes for the

147 photosynthetic enzyme rubisco; Clegg, 1993) for each psychoactive plant taxon was obtained

148 from GenBank database http://www.ncbi.nlm.nih.gov/genbank using BLASTN (e-value=0,

149 query coverage $>50 \%$; Altschul et al., 1990). If there are multiple species within the genus, only

150 the genus name was indicated. The $r b c L$ sequences were not available in GenBank for the

151 following species: Calea ternifolia, Calliandra anomala, Crocus sativus, Horsfieldia

152 australiana, Iochroma fuchsioides, Juniperus recurva, Justicia pectoralis, Lactuca virosa,

153 Ledum palustre, Lonchocarpus violaceus, Nymphaea ampla, Pachycerus pectenaboriginum,

154 Psychotria viridis, Ptychopetalum olacoides, Psidium guajava, Rhynchosia pyramidalis,

155 Sassafras albidum, Sceletium tortuosum, Tanaecium nocturnum, Tilia tomentosa, Urtica urens,

156 Veratrum album, and Virola elongata. In these cases, the $r b c L$ sequence for any species within

157 the corresponding genus was downloaded instead.

158 The $r b c L$ sequences of the psychoactive plants were aligned using default parameters in

159 MAFFT v.7 (Katoh \& Standley, 2013). PhyML (Guindon \& Gascuel, 2003) was utilized to

160 reconstruct the phylogeny applying the general time reversible (GTR) DNA model (Tavaré, 
161 1986) with aLRT (approximate likelihood ratio test) Shimodaira-Hasegawa-like (SH-like)

162 branch support (Simmons \& Norton, 2014) and 100 bootstrap replicates. ITOL (Interactive Tree

163 of Life, www.itol.embl.de), a web-based tool used for the display and manipulation of

164 phylogenetic trees (Letunic \& Bork, 2006), was used to highlight and map the traits in Table 1

165 (indigenous culture, psychoactive uses). Affected neurotransmitter (NT) systems (Table 2) for

166 the main psychoactive families were also added to the phylogeny. Cosmetic editing of the ITOL

167 results was completed in Adobe Illustrator CS4.

\section{Results}

169

The 126 psychoactive seed plant taxa belong to 56 families and 31 orders (Table 1) and together comprise $1.6 \%$ of the total generic diversity for these families. The phylogeny reflects expected relationships (Angiosperm Phylogeny Group/APG IV, 2016). Within eudicots there seems to be cultural bias of psychotropic use toward asterid members (61) vs. rosids (31).

173 Nonetheless, the scattered distribution of psychoactive taxa throughout the angiosperm

174 phylogeny suggests that psychoactive phytochemicals have evolved multiple times throughout

175 angiosperm evolution. However, certain families are more diverse with at least 3 or more genera:

176 Myristicaceae, Papaveraceae, Malvaceae, Fabaceae, Cactaceae, Asteraceae, Convolvulaceae,

177 Solanaceae, Lamiaceae, Rubiaceae, Apocynaceae. However, psychoactive diversity within these

178 families may be positively correlated with the family's generic diversity. To test this, a

179 Pearson's product moment correlation coefficient was calculated to test the relationship between

180 the number of psychoactive genera in our study versus the generic diversity of each family (from

181 Christenhusz \& Byng, 2016). Taxonomically diverse families like Asteraceae and Rubiaceae

182 (>500 genera each) did not always have proportionally higher number of psychoactive genera

183 with the correlation coefficient very weakly positive $(r=0.004)$. However, Myristicaceae $(4$ 
184 psychoactive genera out of 21 total), Papaveraceae (4/42), Cactaceae (5/127), Convolvulaceae

185 (4/53), Solanaceae (16/100), Lamiaceae (8/241), Apocynaceae (7/366) have a disproportionate

186 number $(>1.6 \%)$ of their family's generic diversity psychoactive. We focused on the

187 neurotransmitter systems affected by psychotropic members of these families as well as

188 psychoactive members in the inherently diverse families of Fabaceae, Malvaceae, Rubiaceae, 189 and Asteraceae (Fig. 1).

190 Unrelated families may exert similar psychoactive effects (Fig. 1). Cactaceae, Fabaceae,

191 Myristicaceae, Convolvulaceae, and Solanaceae are mainly hallucinogens, though they are

192 unrelated. Of the five cultural groups, Native Americans have traditionally used the most

193 psychoactives (49/126) with predilection for hallucinogens (Fig. 2) in Cactaceae, Fabaceae,

194 Convolvulaceae. These families mainly work as serotonin receptor agonists (Fig. 1; Table 2), the

195 same mechanism as hallucinogenic Myristicaceae that has been used in Australasia and

196 Indomalaya. Members of Solanaceae have also been used as hallucinogens, predominantly by

197 Native Americans and Europeans, but act via a different mechanism — as acetylcholine

198 antagonists. Hallucinogenic asterids are also often used as aphrodisiacs $(16 / 30=53 \%$ vs.

$1994 / 18=22 \%$ hallucinogenic rosids).

200 The unrelated Papaveraceae and Lamiaceae similarly show sedative/narcotic qualities,

201 another popular psychoactive effect among different cultural groups (Fig. 2). However, they

202 affect different neurotransmitter systems with Papaveraceae working mainly as opioid receptor

203 agonists. Lamiaceae work as receptor agonists of gamma-amino butyric acid (GABA), which

204 also mediates the family's anxiolytic effects. Psychoactive members of these families also tend

205 to exhibit analgesic effects.

206 Plants with anxiolytic and antidepressant properties are relatively sparse (Fig. 1, 2), with 
207 Europeans showing slightly increased use of these plants. Members of Apocynaceae and

208 Rubiaceae that show an antidepressant effect facilitate this effect by increasing synaptic levels of

209 monoamine neurotransmitters (serotonin, dopamine, noradrenaline; Fig. 1; Table 2). In contrast,

210 plants with stimulating effects are numerous and randomly distributed throughout the phylogeny,

211 exhibiting varying mechanisms of action (see Malvaceae and Rubiaceae, Fig. 1; Table 2).

212

213 Discussion

214 The phylogenetic distribution of psychoactive plants shows multiple evolutionary origins

215 and provides evidence for the adaptive benefit of phytochemicals that are psychoactive in

216 animals. It has been hypothesized that mammals may have sought plants with these

217 phytochemicals that were chemically similar to endogenous neurotransmitters to augment their

218 nutrition, as well as to facilitate survival, alleviating pain and hunger (Sullivan \& Hagen, 2002).

219 Whether this phylogenetic distribution, showing multiple independent origins of psychoactive

220 plants, is due to co-evolutionary mutualism with animals remains to be tested. However, it is

221 clear that certain psychoactive effects are concentrated in certain groups, which demonstrates

222 that psychoactive phytochemicals are phylogenetically clustered. Phylogenetic clustering of

223 certain secondary metabolites (Wink, 2003; Wink, 2010; Wink, 2013) and of medicinal traits

224 (Saslis-Lagoudakis et al., 2012; Saslis-Lagoudakis et al., 2015; Xavier \& Molina, 2016) have

225 also been revealed in other studies.

226 In the phylogeny, 11 of 56 plant families have more psychoactive genera (three or more)

227 compared to others. Accounting for these families' total generic diversity shows that

228 Myristicaceae, Papaveraceae, Cactaceae, Convolvulaceae, Solanaceae, Lamiaceae, and

229 Apocynaceae have a disproportionate number of psychoactive genera. The psychoactive 
230 diversity of the other families, Fabaceae, Malvaceae, Asteraceae, and Rubiaceae, may be an

231 artifact of their overall higher generic diversity. Nonetheless, we see a pattern where these plant

232 families are being used for similar psychoactive applications by different cultures, a pattern of

233 cultural convergence (Xavier \& Molina, 2016) with bias, interestingly, for plants with

234 hallucinogenic and sedative/narcotic potential.

235 Pharmacology of hallucinogenic plants. The use of hallucinogens is widespread in

236 cultures which assigned positive meaning to the experienced altered state of consciousness, such

237 as allowing the user access to the spiritual world (Júnior et al., 2015). Hallucinogens used in

238 divination and religious healing (i.e. entheogens) may have played a significant role in human

239 evolution (Schultes, Hofmann \& Rätsch, 2001). Native Americans prolifically used

240 hallucinogens, but hallucinogenic use seems to be lower in temperate Asia. Increased

241 hallucinogenic use among indigenous peoples of Brazil (South America) was also reported by

242 Rodrigues \& Carlini (2006).

243 In our study we find hallucinogenic plants in Myristicaceae, Fabaceae, Cactaceae, and

244 Convolvulaceae mainly acting as serotonin receptor agonists, a case of mechanistic convergence

245 where unrelated families exert the same psychoactive effect by affecting identical

246 neurotransmitter systems. Mescaline is the serotonergic chemical in Cactaceae, while DMT

247 (N,N-dimethyltryptamine) and bufotenin (Polya, 2003) have the same effect and evolved

248 independently in hallucinogenic taxa in Fabaceae (Wink, 2013). Serotonin itself occurs in

249 fabaceous Mucuna pruriens (Polya, 2003), a hallucinogen and aphrodisiac in Ayurvedic

250 medicine (Lampariello et al., 2012). DMT also exists in Virola of the unrelated Myristicaceae

251 (Polya, 2003), and the alkaloid, elemicine, in confamilial Myristica fragrans transforms into a

252 mescaline-like molecule (Rätsch, 2005). 
254 alkaloids that work also as serotonin receptor agonists (Polya, 2003; Kennedy, 2014). Yet

255 interestingly, these ergot alkaloids originate from ascomycetous symbiotic fungi (Beauliet et al.,

256 2013). Though endophytic fungi can produce some active metabolites originally attributed to

257 plants (Wink 2008; Wink et al., 2010; Nicoletti \& Fiorentino, 2015), which may confound

258 interpretation of the phylogeny, this was not the case, so far, for the other main psychoactive

259 families in our study. On the other hand, hallucinogenic taxa in the closely related Solanaceae

260 work on a different mechanism. Its tropane alkaloids such as scopolamine and atropine act as

261 muscarinic receptor antagonists, inhibiting acetylcholine transmission (Spinella, 2001).

262 Interestingly, in another asterid member, Salvia divinorum (Lamiaceae), the diterpene, salvinorin

263 A, possibly works as a hallucinogen through its action on specific opioid receptors (kappa)

264 (Willmore-Fordham et al., 2007), the same receptor modulated by the alkaloid ibogaine in

265 hallucinogenic Tabernanthe iboga (Apocynaceae; Spinella, 2001). Various unrelated taxa

266 seemingly achieve their hallucinogenic effects by modulating serotonin, acetylcholine, and/or

267 endogenous opioids.

268 It is interesting that in many hallucinogenic asterids, aphrodisiac effects are quite

269 common (see Asteraceae, Solanaceae, Apocynaceae). In members of Solanaceae this effect may

270 be due to dopamine increase from cholinergic antagonism (Spinella, 2001). Dopamine is

271 important in sexual arousal and orgasm (Krüger, Hartmann \& Schedlowski, 2005). This

272 neurotransmitter is also modulated by ibogaine in T. iboga (Wells, Lopez \& Tanaka, 1999),

273 which is also traditionally used as an aphrodisiac along with other Apocynaceae members. In

274 another asterid family, Asteraceae, it is not clear which of its phytochemical constituents produce

275 psychoactive effects, except perhaps for wormwood (Artemisia spp.) wherein the 
276 monoterpenoid, thujone, antagonizes the main inhibitory neurotransmitter, gamma-aminobutyric

277 acid (GABA), resulting in its stimulant, almost convulsant, effects (Höld et al., 2000). However,

278 the great diversity of sesquiterpene lactones prevalent in the family (Chadwick et al., 2013) are

279 likely implicated in its hallucinogenic and aphrodisiac potential (Fig. 1; Table 2). These findings

280 motivate further research into these asterid families as new therapeutics for sexual dysfunction.

Pharmacology of plants with sedative and analgesic effects. Dr. W. E. Dixon, well-

282

known British pharmacologist of his time, once commented that narcotic indulgences reflect the

283

sad paradox that humans seemed to get their "chief pleasures in life by escaping out of life"

284 (Narcotic plants, 1928: 252). There may be truth to this as narcotic/sedative effects were

285

commonly sought for by various cultures, second to hallucinogens, with members of

Papaveraceae and Lamiaceae traditionally used for this purpose. Opium poppy of Papaveraceae

has long been known to ancient Greeks and Sumerians and is considered one of the most

important medicinal plants in history. Its opium latex is the source of $>30$ alkaloids including

289

morphine and codeine, which bind to opioid receptors, promoting sedation and analgesia

290

(Heinrich et al., 2012). Though there are other members of Papaveraceae that have been used by

Asians and Native Americans for sedation and pain relief (Rolland et al., 1991; Brahmachari,

Gorai \& Roy, 2013; Shang et al., 2015), the substances responsible for their effects are not well

characterized as in opium poppy, but it is possible that their effects are also mediated via opioid receptors (Shang et al., 2015) and at least in Eschscholzia californica (California poppy) via the GABAergic system (Fedurco et al. 2015). different pathways. Tropane alkaloids in Solanaceae (Wink, 2003), particularly scopolamine, promote sedation through depression of the central nervous system resulting from anticholinergic 
299 activity (Renner, Oertel, \& Kirch 2005). In Lamiaceae, this effect is mainly facilitated via the

300 GABAergic pathway (Shi et al., 2014), with leonurine (Rauwald et al., 2015) and essential oil

301 components (Lis-Balchin \& Hart, 1999; Wink, 2003; Awad et al., 2009; Shi et al., 2014; Ferlemi

302 et al. 2015) as the primary chemicals that increase GABA. Coincidentally, Lamiaceae members

303 also possess analgesic effects, but the pharmacology is unclear (Hajhashemi, Ghannadi \& Sharif,

304 2003; Dobetsberger \& Buchbauer, 2011) and may reflect the antinociceptive properties of

305 activation of GABA receptors (Enna \& McCarson, 2006). Salvia divinorum, however, does not

306 contain essential oils (Rätsch, 2005), but has been pharmacologically shown to exert analgesic

307 quality through activation of the same opioid receptors (kappa) implicated in its hallucinogenic

308 effect (Willmore-Fordham et al., 2007), a mechanism different from the other Lamiaceae species

309 here. Some members of the distantly related Rubiaceae, including Psychotria colorata

310 (Elisabetsky et al., 1995) and Mitragyna speciosa (Suhaimi et al., 2016), have also shown similar

311 opiate-like antinociceptive properties, confirming their traditional uses. Repeated evolution of

312 phytochemicals with affinity for animal opioid receptors may imply some adaptive benefit to

313 plants.

314

Pharmacology of plants with anxiolytic and antidepressant effects. The relatively sparse

315 distribution of anxiolytic and antidepressant plants in the phylogeny compared to hallucinogens

316 and sedatives, suggests that there is less cultural utility for plants with these psychoactive

317 properties. In the US there is a cultural aspect to the pathogenesis of anxiety and depression with

318 minority groups reporting lower incidence compared to whites (Hofmann, Asnaani \& Hinton,

319 2010). The definition itself of depression is wrought with Western assumptions of individual

320 happiness, which is in contrast to other cultures' view of happiness arising from social

321 interdependence (Chentsova-Dutton, Ryder \& Tsai, 2014). This may explain why these 
322 psychoactive uses were less prevalent compared to hallucinogenic, stimulant and sedative 323 applications.

324 Sedative members of Lamiaceae often possess anxiolytic qualities (Fig. 1), and this is 325 probably due to overlapping effects on GABA (Tallman et al., 2002). Phytol, an alcohol in 326 essential oils (Costa et al., 2014) has been shown to increase GABA. Rosmarinic acid in 327 rosemary (R. officinalis) and lemon balm (M. officinalis), both Lamiaceae, also works as GABA 328 transaminase inhibitor preventing GABA catabolism (Awad et al., 2009). In members of Apocynaceae and Rubiaceae (Gentianales) that show anxiolytic and antidepressant effects, another mechanism may be involved. Rauvolfia serpentina

331 (Apocynaceae) is used in Ayurvedic medicine to treat depression (Mamedov, 2005). In Africa, 332 the confamilial T. iboga is used as a stimulant to combat fatigue and hunger, but may have 333 potential in easing depressive symptoms (Nigg and Seigler, 2013). Pausinystalia yohimbe

334 (Rubiaceae) has stimulating effects on the nervous system and has been used to increase libido 335 by men in central Africa (Rätsch, 2005). The confamilial M. speciosa has also been used as 336 stimulant to counteract fatigue and increase endurance for work in Southeast Asia (Idayu et al., 337 2011). The main chemical constituents of these closely related families are indole alkaloids that 338 generally increase synaptic levels of the monoamine neurotransmitters, serotonin, dopamine and 339 noradrenaline by various mechanisms including inhibition of transport and reuptake (Wells, 340 Lopez \& and Tanaka, 1999; Zheng, Fan \& Liu, 2013; Kennedy, 2014). The unrelated but

341 popular herbal antidepressant, St. John's wort (Hypericum perforatum, Hypericaceae; Spinella, 342 2001), as well as pharmaceutical antidepressants, produces its effects (Feighner, 1999) via the 343 same mechanism of reuptake inhibition. 
345 ethnopharmacological studies of plants from South Africa, Heinrich \& Jäger (2015) also

346 discovered two other Apocynaceae species that exhibited high affinity to the serotonin

347 transporter. Interestingly, these plants were also being used by traditional healers to treat those

348 who were "being put down by the spirits". A primary side effect of many conventional

349 antidepressants is sexual dysfunction (Higgins, Nash, \& Lynch, 2010), which seems to contradict

350 the aphrodisiac effect exhibited by $T$. iboga and $P$. yohimbe, in addition to their antidepressant

351 effects. This suggests that members of Gentianales may be exploited as novel pharmaceuticals

352 for depression without the known side effects of sexual dysfunction.

Pharmacology of plants with stimulating effects. Plants traditionally used as stimulants

354

355

356

357

358

359

360

361

362

363

364

365

366

are numerous and scattered throughout the phylogeny, indicating that stimulant phytochemicals

have evolved multiple times independently in different lineages and may confer some

evolutionary benefit. A few display paradoxical effects as both stimulating and sedating, such as marijuana (Block et al., 1998) and M. speciosa (Rätsch, 2005), which may be attributed to dosage, idiosyncrasies, or antagonistic phytochemicals.

Albeit belonging to diverse families, coffee (Coffea arabica, Rubiaceae), yerba mate (Ilex paraguariensis, Aquifoliaceae), kola (Cola spp., Malvaceae), tea (Camellia sinensis, Theaceae), and guarana (Paullinia cupana, Sapindaceae), all contain caffeine, a xanthine alkaloid, which acts as a stimulant through antagonism of adenosine receptors, interfering with the binding of the inhibitory endogenous adenosine (Rätsch, 2005). Yohimbe (P. yohimbe), though confamilial with coffee, contains the indole alkaloid, yohimbine, which binds to adrenergic and serotonin receptors (Polya, 2003), and is structurally and mechanistically similar to other stimulant alkaloids found in diverse plant groups such as ergot alkaloids in Convolvulaceae, ibogaine in $T$. 
367 iboga and Voacanga sp. (Apocynaceae), and harmaline in Peganum harmala (Nitrariaceae) 368 (Polya, 2003).

369 Within the same family, particularly Solanaceae, contrasting effects and mechanisms may

370 also be observed. Though many solanaceous members contain tropane alkaloids that work as

371 anticholinergic hallucinogens with incapacitating effects, tobacco exerts stimulant activity

372 through an opposite mechanism, with nicotine, a pyrrolidine alkaloid, promoting acetylcholine

373 transmission. However, tropane alkaloids are not unique to Solanaceae. Cocaine, found in the

374 unrelated E. coca (Erythroxylaceae), suggests that chemically similar alkaloids may evolve in

375 divergent lineages (i.e. convergent evolution) or alternatively, certain metabolic pathways have

376 been evolutionarily conserved throughout plant evolution and differential gene regulation is

377 responsible for the expression of this pathway (Wink, 2003; Wink, 2008; Wink et al., 2010;

378 Weng, 2014). These may account for the presence of ephedrine in the gymnosperm Ephedra spp.

379 (Ephedraceae; Polya, 2003) and the unrelated angiosperms Sida acuta (Malvaceae; Prakash,

380 Varma \& Gosal, 1981) and Catha edulis (Celastraceae; Polya, 2003). Ephedrine, a

381 phenethylamine that mimics noradrenaline, stimulates the adrenergic receptor system, and thus

382 the sympathetic nervous system responsible for the "fight-and-flight" response (Polya, 2003;

383 Rätsch, 2005).

384 It is notable that, even within the same family, the stimulant phytochemicals are

385 chemically diverse. This phylogenetic pattern may indicate that stimulant chemicals may be

386 more evolutionarily labile than hallucinogenic and sedative phytochemicals that seem to be more

387 phylogenetically conserved within the family. As to why this is begs further inquiry, but hints at

388 the evolutionary benefits of these chemically diverse plant psychoactive compounds that have 
389 evolved multiple times among seed plants, possibly with multifarious roles other than to function 390 solely as allelochemicals.

391

392 Conclusion

Phylogenetic analysis has demonstrated multiple evolutionary origins of traditionally

394 used psychoactive plant groups. Whether this pattern is due to repeated co-evolutionary

395 mutualism with animals remains to be tested. Psychoactive diversity of some highlighted

396 families is probably due to the inherent elevated diversity in these families. However, other plant

397 families have a disproportionate number of psychoactive genera, and their phytochemical and

398 psychoactive traits show phylogenetic clustering, with different cultures converging on

399 geographically-disparate members of these families for similar uses: Myristicaceae, Cactaceae,

400 Convolvulaceae, and Solanaceae as hallucinogens; Papaveraceae, Lamiaceae for analgesia and

401 sedation; Apocynaceae for antidepressant effects. In certain unrelated families with the same

402 psychoactive effect, the same neurotransmitter systems were also affected, i.e., mechanistic

403 convergence. However, this was not the case for plants with stimulant effects, where confamilial

404 taxa possess chemically diverse stimulant alkaloids, and chemically similar stimulant alkaloids

405 exist in diverse lineages. Endophytic fungi can also produce some active metabolites originally

406 attributed to plants (Wink, 2008; Wink et al., 2010; Nicoletti \& Fiorentino, 2015), and this

407 should be considered when interpreting the phylogeny.

408 Though we may have missed other psychotropic taxa, our study still provides insight into

409 the ethnobotanical origins of psychoactive plant use. The addition of these missing taxa may

410 only serve to corroborate our conclusion of widespread human dependence on psychoactive

411 plants and highlight other important psychoactive families and their pharmacology. The brain is 
412 perhaps the most complex domain of the human body (Singer 2007), and therefore brain

413 disorders are complex pathologies themselves (Margineanu, 2016). Ethnobotanical research on

414 how various human cultures have exploited herbal therapy through time to treat neurological

415 afflictions will continue to provide insight into the etiology of these diseases and the success of

416 folkloric treatments. Yet, the astounding diversity of plant-based medicines may be better

417 appreciated within an evolutionary context that can reveal phylogenetic patterns that may guide

418 future drug discovery (Saslis-Lagoudakis et al., 2012; Xavier \& Molina, 2016). Though

419 chemically similar psychoactive chemicals may exist in phylogenetically unrelated lineages,

420 suggesting convergent evolution or differential gene regulation of common metabolic pathways

421 (Wink, 2003; Wink, 2008; Wink et al., 2010), the majority of traditionally used psychoactive

422 plants generally display phylogenetic conservatism in phytochemistry and pharmacology, and

423 may be explored as novel therapeutics for neurological disorders such as depression, anxiety,

424 pain, insomnia and sexual dysfunction, reinforcing the potential of plant psychoactives as

425 "springboards for psychotherapeutic drug discovery" (McKenna, 1996).

426

\section{ACKNOWLEDGMENTS}

428

This research was conceived as part of NA's MSc thesis, and we are grateful to the King

Abdullah scholarship program (of Saudi Arabia) and to NA's family for various forms of support. We also thank Joseph Morin and Timothy Leslie for reviewing earlier drafts of this

431 manuscript. We are equally grateful to the reviewers for their constructive comments.

432

433

434 


\section{REFERENCES}

436

437 Altschul, S. F., Gish, W., Miller, W., Myers, E. W., Lipman, D. J. (1990). Basic local alignment

438 search tool. Journal of Molecular Biology 215:403-410. Doi:10.1016/S0022-2836(05)80360-2.

439

440 Arulmozhi, S., Mazumder, P. M., Sathiya, N. P., Thakurdesai, A. (2012). Antianxiety and 441 antidepressant activity of leaves of Alstonia scholaris Linn R.Br. Pharmacologia 3:239-48.

443 Awad, R., Arnason, J. T., Trudeau, V., Bergeron, C., Budzinski, J. W., Foster, B. C., Merali, Z.

444 (2003). Phytochemical and biological analysis of skullcap (Scutellaria lateriflora $\mathrm{L}$.$) : a$

445 medicinal plant with anxiolytic properties. Phytomedicine 10:640-649. Doi: 10.1078/0944-7113$446 \quad 00374$

447

448 Awad, R., Muhammad, A., Durst, T., Trudeau, V. L., Arnason, J. T. (2009). Bioassay-guided

449 fractionation of lemon balm (Melissa officinalis L.) using an in vitro measure of GABA

450 transaminase activity. Phytotherapy Research 23:1075-1081. Doi:10.1002/ptr.2712.

451

452 Beaulieu, W. T., Panaccione, D. G., Hazekamp, C. S., Mckee M. C., Ryan, K. L., Clay, K. 453 (2013). Differential allocation of seed-borne ergot alkaloids during early ontogeny of morning 454 glories (Convolvulaceae). Journal of Chemical Ecology 39:919-930. Doi: 10.1007/s10886-013455 0314-z. 456 
457 Block, R. I., Erwin, W. J., Farinpour, R., \& Braverman, K. (1998). Sedative, stimulant, and other 458 subjective effects of marijuana: relationships to smoking techniques. Pharmacology

459 Biochemistry and Behavior 59:405-412. Doi: 10.1016/S0091-3057(97)00453-X.

460

461 Brahmachari, G., Gorai, D., Roy, R. (2013). Argemone mexicana: chemical and pharmacological 462 aspects. Revista Brasileira de Farmacognosia, 23:559-567.

463

464 Cardoso, F. A. G., Uliano, V. G., Bohatch Júnior, M. S., Matkovski, P. D., Alberton, M. D., 465 Albuquerque, C. A., Magro, D., Delwing, D., Barauna, S. C. (2015). Antidepressant-like effect 466 of Tabernaemontana catharinensis hydroalcoholic extract in mice: Evidence of the involvement 467 of 5-HT 1A receptors. Psychology \& Neuroscience, 8:280. Doi:

468 http://dx.doi.org/10.1037/h0101055.

469

470 Feighner, J. P. (1999). Mechanism of action of antidepressant medications. The Journal of 471 Clinical Psychiatry 60(4):4-11; discussion 12-3.

472

473 Chadwick, M., Trewin, H., Gawthrop, F., Wagstaff, C. (2013). Sesquiterpenoids lactones:

474 benefits to plants and people. International Journal of Molecular Sciences 14:12780-12805. Doi: 475 doi:10.3390/ijms 140612780

476

477 Chaudhary, S., Chandrashekar, K. S., Pai, K. S. R., Setty, M. M., Devkar, R. A., Reddy, N. D., 478 Shoja, M. H. (2015). Evaluation of antioxidant and anticancer activity of extract and fractions of 
479 Nardostachys jatamansi DC in breast carcinoma. BMC Complementary and Alternative

480 Medicine 15:1. Doi:10.1186/s12906-015-0563-1.

481

482 Chentsova-Dutton, Y., Ryder, A., Tsai, J.L. (2014). Understanding depression across cultural 483 contexts. In I. Gotlib \& C. Hammen, eds. Handbook of Depression, 3rd edition, New York, NY: 484 Guilford Press.

485

486 Christenhusz, M. J., Byng, J. W. (2016). The number of known plants species in the world and 487 its annual increase. Phytotaxa 261:201-217. Doi: http://dx.doi.org/10.11646/phytotaxa.261.3.1 488

489 Clarke, R., Merlin, M. (2013). Cannabis: evolution and ethnobotany. Los Angeles, California: 490 University of California Press.

491

492 Clegg, M. T. (1993). Chloroplast gene sequences and the study of plant evolution. Proceedings 493 of the National Academy of Sciences 90:363-367.

494

495 Costa, J. P., de Oliveira, G. A. L., de Almeida, A. A. C., Islam, M. T., de Sousa, D. P., de Freitas, 496 R. M. (2014). Anxiolytic-like effects of phytol: possible involvement of GABAergic

497 transmission. Brain research 1547:34-42. Doi: 10.1016/j.brainre s.2013.12.003. 498 
499 Danjuma, N. M., Chindo, B. A., Abdu-Aguye, I., Anuka, J. A., Hussaini, I. M. (2014).

500 Psychopharmacological properties of saponins from Randia nilotica stem bark. Pharmaceutical 501 biology 52:1-7. Doi: 10.3109/13880209.2013.784343.

502

503 Dobetsberger, C., Buchbauer, G. (2011). Actions of essential oils on the central nervous system: 504 An updated review. Flavour and Fragrance Journal 26:300-316. Doi: 10.1002/ffj.2045.

505

506

Doukkali, Z., Taghzouti, K., Bouidida, E. H., Nadjmouddine, M., Cherrah, Y., Alaoui, K. (2015).

507 Evaluation of anxiolytic activity of methanolic extract of Urtica urens in a mice

508 model. Behavioral and Brain Functions 11:1. Doi: 10.1186/s12993-015-0063-y.

509

510 Elisabetsky, E., Amador, T. A., Albuquerque, R. R., Nunes, D. S., Carvalho, A. (1995).

511 Analgesic activity of Psychotria colorata (Willd. ex R. \& S.) Muell. Arg. alkaloids. Journal of

512 Ethnopharmacology 48:77-83. Doi: 10.1016/0378-8741(95)01287-N.

513

514 Enna, S. J., McCarson, K. E. (2006). The role of GABA in the mediation and perception of 515 pain. Advances in Pharmacology 54:1-27. Doi: 10.1016/S1054-3589(06)54001-3.

516

517 Fan, J., Wang, Y.,, Wang, X., Wang, P., Tang, W., Yuan, W., Kong, L., Liu, Q. (2015). The

518 antitumor activity of Meconopsis horridula Hook, a traditional Tibetan Medical Plant, in murine

519 leukemia L1210 cells. Cellular Physiology and Biochemistry 37:1055-1065. Doi:

$520 \quad 10.1159 / 000430231$.

521 
522 Farouk, L., Laroubi, A., Aboufatima, R., Benharref, A., Chait, A. (2008). Evaluation of the

523 analgesic effect of alkaloid extract of Peganum harmala L.: Possible mechanisms

524 involved. Journal of Ethnopharmacology 115:449-454. Doi: 10.1016/j.jep.2007.10.014.

525

526 Fedurco, M., Gregorová, J., Šebrlová, K., Kantorová, J., Peš, O., Baur, R., Sigel, E., Táborská, E.

527 (2015). Modulatory effects of Eschscholzia californica alkaloids on recombinant GABAA

528 receptors. Biochemistry Research International 2015:9.

529 Doi:http://dx.doi.org/10.1155/2015/617620.

530

531 Ferlemi, A. V., Katsikoudi, A., Kontogianni, V. G., Kellici, T. F., Iatrou, G., Lamari, F. N.,

532 Tzakos, A. G., Margarity, M. (2015). Rosemary tea consumption results to anxiolytic-and anti-

533 depressant-like behavior of adult male mice and inhibits all cerebral area and liver cholinesterase

534 activity; phytochemical investigation and in silico studies. Chemico-biological

535 Interactions 237:47-57. Doi: 10.1016/j.cbi.2015.04.013.

536

537 Foster, S., Duke, J. A. (2000). A Field Guide to Medicinal Plants and Herbs of Eastern and

538 Central North America. Boston: Houghton Mifflin Harcourt.

539

540 Fürstenberg-Hägg, J., Zagrobelny, M., Bak, S. (2013). Plant defense against insect

541 herbivores. International Journal of Molecular Sciences 14:10242-10297. Doi:

$542 \quad 10.3390 /$ ijms 140510242.

543 
544 Galani, V. J., Patel, B. G., Patel, N. B. (2010). Argyreia speciosa (Linn. f.) sweet: A

545 comprehensive review. Pharmacognosy Reviews 4:172. Doi: 10.4103/0973-7847.70913.

546

547 Gericke, N., Viljoen A. M. (2008). Sceletium--a review update. Journal of Ethnopharmacology

548 119:653-63. Doi: 10.1016/j.jep.2008.07.043.

549

550 Grundmann, O., Nakajima, J., Seob, S., Butterwecka, V. (2007). Anti-anxiety effects of

551 Apocynum venetum L. in the elevated plus maze test. Journal of Ethnopharmacology 110:406-

552 411. Doi:0.1016/j.jep.2006.09.035.

553

554 Guindon, S., Gascuel, O. (2003). A simple, fast, and accurate algorithm to estimate large 555 phylogenies by maximum likelihood. Systematic Biology 52:696-704.

556

557 Hajhashemi, V., Ghannadi, A., Sharif, B. (2003). Anti-inflammatory and analgesic properties of 558 the leaf extracts and essential oil of Lavandula angustifolia Mill. Journal of Ethnopharmacology 559 89:67-71. Doi: 10.1016/S0378-8741(03)00234-4.

560

561 Halpern, J. (2004). Hallucinogens and dissociative agents naturally growing in the United States.

562 Pharmacology \& Therapeutics 102:131-138. Doi: 10.1016/j.pharmthera.2004.03.003.

563 Heinrich, M., Barnes, J., Gibbons, S., Williamson, E. M. (2012). Fundamentals of

564 Pharmacognosy and Phytotherapy. Elsevier Churchill Livingstone.

565

566 Heinrich, M., Jäger, A. K. (Eds.). (2015). Ethnopharmacology. UK: John Wiley \& Sons. 
568 Higgins, A., Nash, M., Lynch, A. M. (2010). Antidepressant-associated sexual dysfunction:

569 impact, effects, and treatment. Drug, Healthcare and Patient Safety 2: 141-150. Doi:

570 10.2147/DHPS.S7634.

571

572 Hofmann, S. G., Asnaani, A., Hinton, D. E. (2010). Cultural aspects in social anxiety and social 573 anxiety disorder. Depression and Anxiety 27:1117-1127. Doi: 10.1002/da.20759.

574

575 Höld, K. M., Sirisoma, N.S., Ikeda, T., Narahashi, T., Casida, J. E. (2000). Alpha-thujone (the 576 active component of absinthe): gamma-aminobutyric acid type A receptor modulation and 577 metabolic detoxification. Proceedings of the National Academy of Sciences 97:3826-3831.

578

579 Hosseinzadeh, H., Noraei, N. B. (2009). Anxiolytic and hypnotic effect of Crocus sativus

580 aqueous extract and its constituents, crocin and safranal, in mice. Phytotherapy Research 23:768581 774. Doi: 10.1002/ptr.2597.

582

583 Howe, G. A., \& Jander, G. (2008). Plant immunity to insect herbivores. Annual Review of Plant 584 Biology 59:41-66. Doi: 10.1146/annurev.arplant.59.032607.092825.

585

586 Idayu, N. F., Hidayat, M. T., Moklas, M. A., Sharida, F., Raudzah, A. R., Shamima, A. R., 587 Apryani, E. (2011). Antidepressant-like effect of mitragynine isolated from Mitragyna speciosa 588 Korth in mice model of depression. Phytomedicine 18:402-407.

589 Doi:10.1016/j.phymed.2010.08.011. 
590

591 Johnson, S. W., North, R. A. (1992). Opioids excite dopamine neurons by hyperpolarization of 592 local interneurons. The Journal of Neuroscience 12:483-488.

593

594 Júnior, W. S. F., Cruz, M. P., Vieira, F. J., Albuquerque, U. P. (2015). An Evolutionary

595 Perspective on the Use of Hallucinogens. In: Evolutionary Ethnobiology (Albuquerque, U. P., De 596 Medeiros, P. M., Casas, A., eds.). Switzerland: Springer International Publishing.

598 Katoh, K., Standley, D. M. (2013). MAFFT multiple sequence alignment software version 7:

599 improvements in performance and usability. Molecular Biology and Evolution 30:772-780.

600

601 Kennedy, D. O. (2014). Plants and the Human Brain. New York: Oxford University Press.

602

603 Knab, T. (1977). Notes concerning use of Solandra among the Huichol. Economic Botany 31:8060486.

605

606 Krüger, T. H., Hartmann, U., Schedlowski, M. (2005). Prolactinergic and dopaminergic 607 mechanisms underlying sexual arousal and orgasm in humans. World Journal of Urology 608 23:130-138. Doi:10.1007/s00345-004-0496-7

609

610 Lampariello, L. R., Cortelazzo, A., Guerranti, R., Sticozzi, C., Valacchi, G. (2012). The magic 611 velvet bean of Mucuna pruriens. Journal of Traditional and Complementary Medicine 2:331612339. 
613

614 Letunic, I., Bork, P., (2006). Interactive Tree of Life. (iTOL): an online tool for phylogenetic tree 615 display annotation. Bioinformatics 23:127-128.

616

617 Lis-Balchin, M., Hart, S. (1999). Studies on the mode of action of the essential oil of Lavender

618 Lavandula angustifolia P. Miller). Phytotherapy Research 13:540-542. Doi: 10.1002/(SICI)1099-

619 1573(199909)13:6<540::AID-PTR523>3.0.CO;2-I

620

621 Lüscher, C., Ungless, M. A. (2006). The mechanistic classification of addictive drugs. PLoS

622 Medicine 3:437. Doi: 10.1371/journal.pmed.0030437.

623

624 Mahler, S. V., Smith, K. S., Berridge, K. C. (2007). Endocannabinoid hedonic hotspot for 625 sensory pleasure: anandamide in nucleus accumbens shell enhances 'liking' of a sweet 626 reward. Neuropsychopharmacology 32:2267-2278. Doi: 10.1038/sj.npp.1301376

627

628 Mamedov, N. (2005). Adaptogenic, geriatric, stimulant and antidepressant plants of Russian Far 629 East. Journal of Cell and Molecular Biology 4:71-75.

630

631 Margineanu, D. G. (2016). Neuropharmacology beyond reductionism - A likely prospect.

632 Biosystems 141:1-9. Doi: 10.1016/j.biosystems.2015.11.010.

633

634 McClatchey, W. C., Mahady, G. B., Bennett, B. C., Shiels, L., Savo, V. (2009). Ethnobotany as a 635 pharmacological research tool and recent developments in CNS-active natural products from 
636 ethnobotanical sources. Pharmacology \& Therapeutics 123:239-254. Doi:

637 10.1016/j.pharmthera.2009.04.002.

638

639 McKenna, D. (1996). Plant hallucinogens: Springboards for psychotherapeutic drug discovery.

640 Behvioural Brain Research 73:109-116. Doi:10.1016/0166-4328(96)00079-4.

641

642 Meira, M., Silva, E. P. D., David, J. M., \& David, J. P. (2012). Review of the genus Ipomoea:

643 traditional uses, chemistry and biological activities. Revista Brasileira de Farmacognosia

$644 \quad 22: 682-713$.

645

646 Merlin, M. D. (2003). Archaeological evidence for the tradition of psychoactive plant use in the 647 old world. Economic Botany 57:295-323.

648

649 Narcotic Plants. (1928). Canadian Medical Association Journal, 19(2), 251-252.

650

651 Nicoletti, R., Fiorentino, A. (2015). Plant bioactive metabolites and drugs produced by 652 endophytic fungi of Spermatophyta. Agriculture 5:918-970. Doi:10.3390/agriculture5040918.

653

654 Nigg, H. N., Seigler, D. (Eds.). (1992). Phytochemical Resources for Medicine and Agriculture. 655 New York: Springer Science \& Business Media.

656 
657 O’Mahony, C. S. (2010). Psychoactive substances: a guide to ethnobotanical plants and herbs, 658 synthetic chemicals, compounds and products. Available from:

659 http://www.thehealthwell.info/node/69579 (Accessed: 12th June 2016).

660

661 Piato, A., Rizon, L., Martins, B., Nunes, D., Elisabetsky, E. (2008). Antidepressant profile of 662 Ptychopetalum olacoides Bentham (Marapuama) in mice. Phytotherapy Research 23:519-524.

663 Doi: $10.1002 /$ ptr.2664

664

665 Polya, G. (2003). Biochemical Targets of Plant Bioactive Compounds: A Pharmacological 666 Reference Guide to Sites of Action and Biological Effects. Boca Raton, Florida: CRC Press.

667

668 Prakash, A., Varma, R. K., \& Ghosal, S. (1981). Alkaloid constituents of Sida acuta, S. humilis, 669 S. rhombifolia and S. spinosa. Planta Medica 43:384-388.

670

671 Pratchayasakul, W., Pongchaidecha, A., Chattipakorn, N., Chattipakorn, S. (2008). Ethnobotany

672 \& ethnopharmacology of Tabernaemontana divaricata. Indian Journal of Medical Research $673 \quad$ 127:317.

674

675 Rätsch, C. (2005). The Encyclopedia of Psychoactive Plants: Ethnopharmacology and its 676 Applications. Rochester: Rochester, Vermont: Park Street Press.

677

678 Rauwald, H. W., Savtschenko, A., Merten, A., Rusch, C., Appel, K., Kuchta, K. (2015).

679 GABAA receptor binding assays of standardized Leonurus cardiaca and Leonurus japonicus 
680 extracts as well as their isolated constituents. Planta Medica 81:1103-1110. Doi: 10.1055/s$6810035-1546234$.

682

683 Renner, U. D., Oertel, R., Kirch, W. (2005). Pharmacokinetics and pharmacodynamics in clinical 684 use of scopolamine. Therapeutic Drug Monitoring 27:655-665.

685

686 Rodrigues, E., Carlini, E. A. (2006). A comparison of plants utilized in ritual healing by two 687 Brazilian cultures: Quilombolas and Kraho Indians. Journal of Psychoactive Drugs 38:285-295. 688 Doi: 10.1080/02791072.2006.10399854.

689

690

Rolland, A., Fleurentin, J., Lanhers, M. C., Younos, C., Misslin, R., Mortier, F., Pelt, J. M.

691 (1991). Behavioural effects of the American traditional plant Eschscholzia californica: sedative 692 and anxiolytic properties. Planta Medica 57:212-216. Doi: 10.1055/s-2006-960076.

693

694 Saslis-Lagoudakis, C. H., Savolainen, V., Williamson, E. M., Forest, F., Wagstaff, S. J., Baral, S. 695 R., Watson, M. F., Pendry, C. A., Hawkins, J. A. (2012). Phylogenies reveal predictive power of 696 traditional medicine in bioprospecting. Proceedings of the National Academy of Sciences 697 109:15835-15840. Doi:10.1073/pnas.1202242109.

698

699 Saslis-Lagoudakis, C. H., Rønsted, N., Clarke, A. C., Hawkins, J. A. (2015). Evolutionary 700 Approaches to Ethnobiology. In: Evolutionary Ethnobiology (Albuquerque, U. P., De Medeiros, 701 P. M., Casas, A., eds.). Switzerland: Springer International Publishing. 
703 Sayin, H, U. (2014). The consumption of psychoactive plants during religious rituals: the root of

704 common symbols and figures in religions and myths. NeuroQuantology 12:726-296.

705

706 Schultes, R. E. (1976). Hallucinogenic plants. New York: Golden Press

707

708 Schultes, R. E., Hofmann, A., Rätsch, C. (2001). Plants of the Gods - Their Sacred, Healing, and 709 Hallucinogenic Powers (2ed.). Rochester, Vermont: Healing Arts Press.

710

711 Shang, X., Wang, D., Miao, X., Wang, Y., Zhang, J., Wang, X., Zhang, Y., Pan, H. (2015).

712 Antinociceptive and anti-tussive activities of the ethanol extract of the flowers of Meconopsis

713 punicea Maxim. BMC Complementary and Alternative Medicine 15:154. Doi: 10.1186/s12906-

714 015-0671-y.

715

716 Shi, Y., Dong, J. W., Zhao, J. H., Tang, L. N., Zhang, J. J. (2014). Herbal insomnia medications

717 that target GABAergic systems: a review of the psychopharmacological evidence. Current

718 Neuropharmacology 12:289-302.

719

720 Shinomol, GK., Muralidhara., Bharath, MM. (2011). Exploring the role of "Brahmi”(Bocopa

721 monnieri and Centella asiatica) in brain function and therapy. Recent Patents on Endocrine,

722 Metabolic \& Immune Drug Discovery 5:33-49.

723 
724 Simmons, M. P., Norton, A. P. (2014). Divergent maximum-likelihood-branch-support values

725 for polytomies. Molecular Phylogenetics \& Evolution 73:87-96. Doi:

726 10.1016/j.ympev.2014.01.018.

727

728 Singer, W. (2007). Understanding the brain. EMBO Reports 8: S16-S19.

729

730 Spinella, M. (2001). The psychopharmacology of herbal medicine: plant drugs that alter mind, 731 brain, and behavior. London: MIT Press.

732

733 Suhaimi, F. W., Yusoff, N. H., Hassan, R., Mansor, S. M., Navaratnam, V., Müller, C. P.,

734 Hassan, Z. (2016). Neurobiology of Kratom and its main alkaloid mitragynine. Brain Research

735 Bulletin. Doi: 10.1016/j.brainresbull.2016.03.015.

736

737 Sullivan, R. J., Hagen, E. H. (2002). Psychotropic substance-seeking: evolutionary pathology or 738 adaptation? Addiction, 97:389-400. Doi: 10.1046/j.1360-0443.2002.00024.x.

739

740 Tallman, J. F., Cassella, J., Kehne, J., Corpora, N. (2002). Mechanism of action of anxiolytics.

741 In: Davis, K. L., Charney, D., Coyle, J. T. Nemeroff, C., (eds.) Neuropsychopharmacology.

742 Philadelphia, Pennsylvania: Lippincott, Williams, \& Wilkins.

743

744 Tavaré, S. (1986). Some probabilistic and statistical problems in the analysis of DNA sequences.

745 In: Miura, R.M. (ed.). Some Mathematical Questions in Biology-DNA Sequence Analysis.

746 Providence, Rhode Island: American Mathematical Society. 
748 The Angiosperm Phylogeny Group. (2016). An update of the Angiosperm Phylogeny Group

749 classification for the orders and families of flowering plants: APG IV. Botanical Journal of the

750 Linnean Society 181:1-20.

751

752 The Plant List (2013). Version 1.1. Available at http://www.theplantlist.org/ (accessed 16 June 753 2016)

754

755 Van Wyk, B.-E., Wink, M. (2014). Phytomedicines, Herbal drugs and Poisons. The University of 756 Chicago Press, Chicago and London Kew Publishing Royal Botanic Gardens, Kew.

757

758 Vetulani, J. (2001). Drug addiction: Part I. Psychoactive substances in the past and presence. 759 Polish Journal of Pharmacology, 53:201-214.

760

761 Vogl, S., Picker, P., Mihaly-Bison, J., Fakhrudin, N., Atanasov, A. G., Heiss, E. H., Wawrosch,

762 C., Reznicek, G., Dirsch, V.M., Saukel, J, Kopp, B. (2013). Ethnopharmacological in vitro

763 studies on Austria's folk medicine — an unexplored lore in vitro anti-inflammatory activities of 71

764 Austrian traditional herbal drugs. Journal of Ethnopharmacology 149:750-771. Doi:

765 10.1016/j.jep.2013.06.007. 
767 Wang, T., Zhang, X., Xie, W. (2012). Cistanche deserticola YC Ma, Desert ginseng: a

768 review. The American journal of Chinese medicine 40:1123-1141. Doi:

769 http://dx.doi.org/10.1142/S0192415X12500838.

770

771 Wells, G. B., Lopez, M. C., Tanaka, J. C. (1999). The effects of ibogaine on dopamine and

772 serotonin transport in rat brain synaptosomes. Brain research bulletin 48:641-647. Doi:

773 10.1016/S0361-9230(99)00053-2.

774

775 Weng, J.K. (2014). The evolutionary paths towards complexity: a metabolic perspective.

776 New Phytologist 201:1141-1149.

777

778 Willmore-Fordham, C. B., Krall, D. M., McCurdy, C. R., Kinder, D. H. (2007). The

779 hallucinogen derived from Salvia divinorum, salvinorin A, has א-opioid agonist discriminative

780 stimulus effects in rats. Neuropharmacology 53:481-486. Doi:

781 10.1016/j.neuropharm.2007.06.008.

782

783 Wink, M. (2003). Evolution of secondary metabolites from an ecological and molecular

784 phylogenetic perspective. Phytochemistry 64:3-19. Doi: 10.1016/S0031-9422(03)00300-5.

785

786 Wink, M. (2008). Plant secondary metabolism: diversity, function and its evolution. Natural 787 Product Communications 3:1205-1216. 
789 Wink, M., Botschen, F., Gosmann, C., Schäfer, H., Waterman, P.G. (2010). Chemotaxonomy

790 seen from a phylogenetic perspective and evolution of secondary metabolism. In M. Wink, ed.

791 Annual Plant Reviews Volume 40: Biochemistry of Plant Secondary Metabolism, $2^{\text {nd }}$ edition

792 Wiley-Blackwell, Oxford, UK. Doi: 10.1002/9781444320503.ch7

793

794 Wink, M. (2013) Evolution of secondary metabolites in legumes (Fabaceae). South African

795 Journal of Botany 89:164-175.

796

797 Wink, M. (2016) Evolution of secondary plant metabolism. In: eLS. John Wiley \& Sons, Ltd:

798 Chichester. DOI: 10.1002/9780470015902.a0001922.pub3.

799

800 Xavier, C., Molina, J. (2016). Phylogeny of medicinal plants depicts cultural convergence among 801 immigrant groups in New York City. Journal of Herbal Medicine 6:1-11. Doi:

802 10.1016/j.hermed.2015.12.002.

803

804 Zheng, M., Fan, Y., Liu, C. (2013). Antidepressant-like effect of flavonoids extracted

805 from Apocynum venetum leaves on brain monoamine levels and dopaminergic system. Journal of 806 Ethnopharmacology 147:108-13. Doi: 10.1016/j.jep.2013.02.015.

807

808

809

810

811 


\section{FIGURES}

813

814 Figure 1. The phylogeny (cladogram) of traditionally used psychoactive plant taxa. The

815 phylogeny conforms to expected groupings (APG IV, 2016). The 11 main plant families are

816 highlighted (top to bottom): Myristicaceae, Papaveraceae, Malvaceae, Fabaceae, Cactaceae,

817 Asteraceae, Convolvulaceae, Solanaceae, Lamiaceae, Rubiaceae, Apocynaceae. Grey circles

818 next to their family names are proportional to total generic diversity within the family with

819 lowest count for Myristicaceae (21genera), and highest with 1623 genera for Asteraceae

820 (Christenhusz and Byng 2016). Branches are coded according to the different cultures (Native

821 American: red solid line; Middle Eastern and African: orange dashed line; European: blue solid

822 line; Indomalayan: green dotted line; Temperate Asia: pink solid line, Australasia: yellow solid

823 line; Multi-cultural: grey solid line). Branches in bold represent bootstrap node support $>50 \%$

824 and SH-like branch support $>0.9$. Psychoactive uses were overlain next to taxon names in

825 columns $(\mathrm{Ha}=$ hallucinogen, $\mathrm{Sm}=$ stimulant, $\mathrm{Ax}=$ anxiolytic, $\mathrm{Ad}=$ antidepressant, $\mathrm{Sd}=$ sedative,

$826 \mathrm{Ag}=$ analgesic, $\mathrm{Ap}=$ aphrodisiac along with the primary neurotransmitters affected by the

827 phytochemical/s exerting the dominant psychoactive effect (delineated with boxes; cf. Table 2).

828 Shaded plant families with phytochemicals that activate certain neurotransmitter systems (e.g.

829 receptor agonists) show the neurotransmitter/s involved with green (bright) background;

830 phytochemicals with inhibitory effects to the NT have red (dark) background. In Asteraceae,

831 neuropharmacology is unclear (???). 

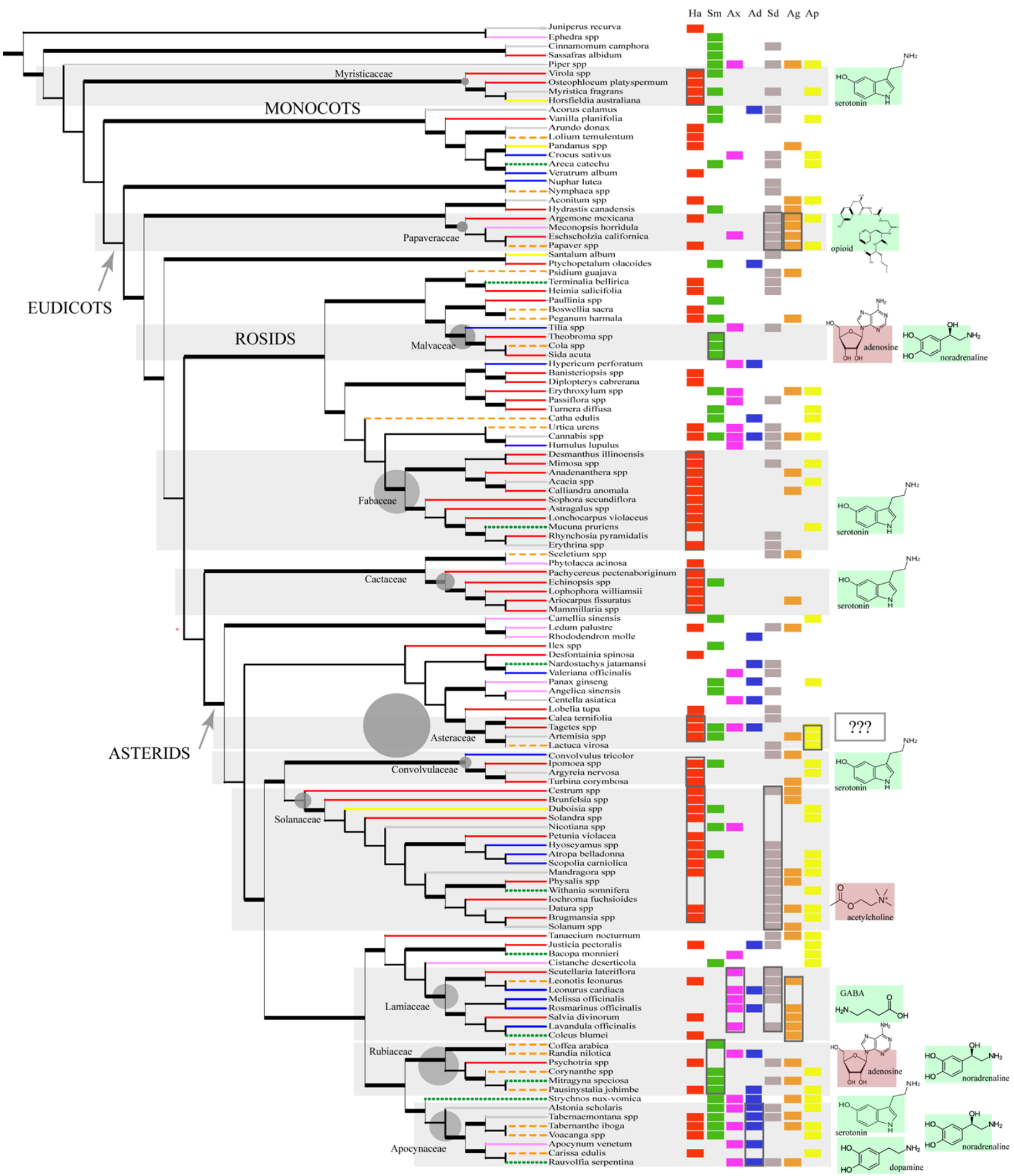

833

834 
835 Figure 2. Cultural distribution of psychoactive applications. Psychoactive plants were

836 categorized according to cultural affiliation and psychoactive uses. Each row shows the

837 distribution of psychoactive uses for plants within a cultural group. Of the 126 psychoactive

838 plant genera, more than half of the plants are used as hallucinogens mostly by Native Americans.

839 Plants with sedative/narcotic qualities are also commonly sought after. Plants with anxiolytic and 840 antidepressant effects are the least popular among different cultures.

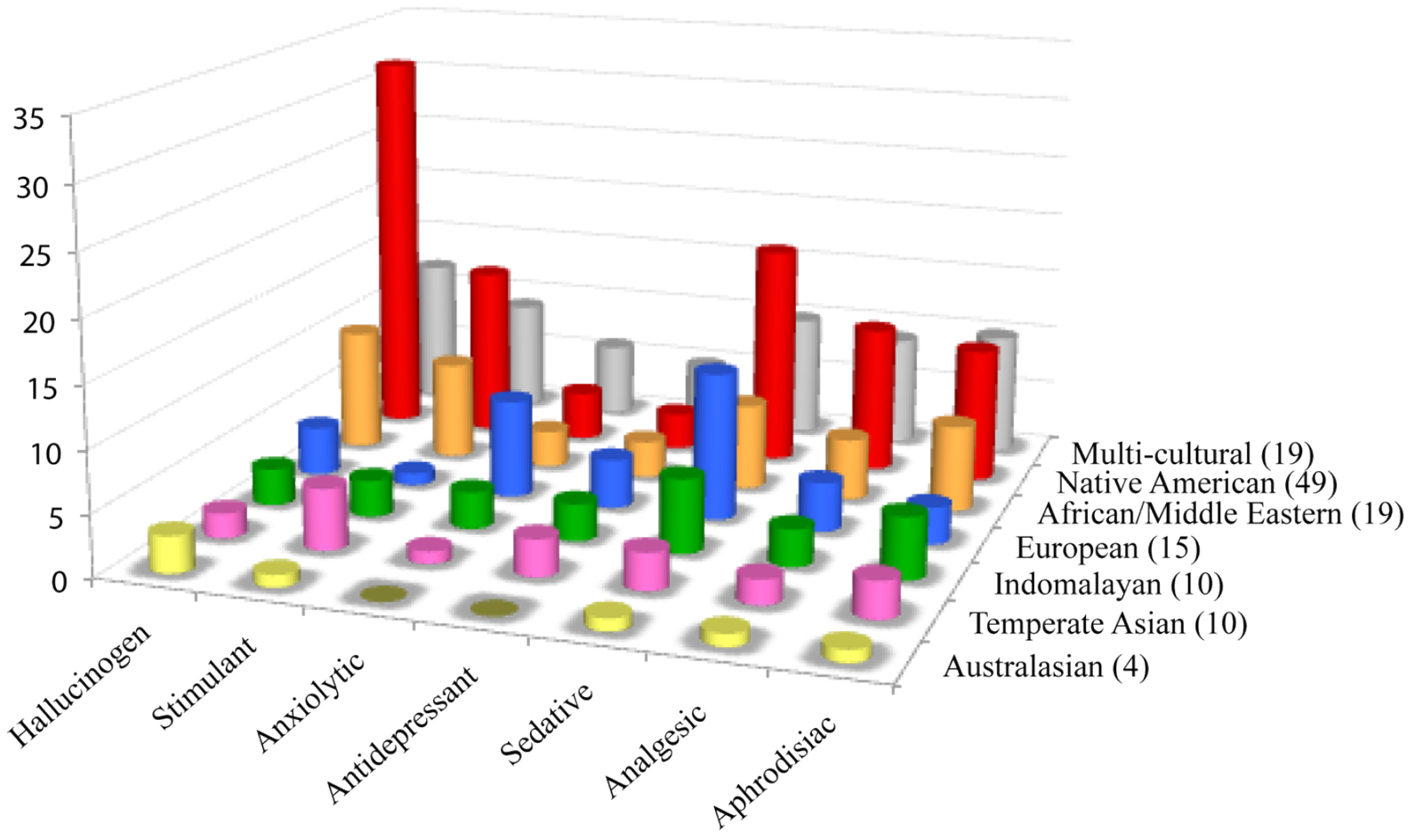

843

844 


\section{PeerJ}


845 Table 1. Psychoactive plant taxa in this study. Culturally diverse psychoactive plant taxa, their uses, indigenous psychoactive cultural

846 origin, and corresponding Genbank numbers.

\begin{tabular}{|c|c|c|c|c|c|}
\hline Family (Order) & $\begin{array}{l}\text { Accepted binomial } \\
\text { name }\end{array}$ & $\begin{array}{l}\text { Common } \\
\text { Name }\end{array}$ & $\begin{array}{l}\text { Indigenous } \\
\text { psychoactive } \\
\text { culture }\end{array}$ & Mechanism of Action & $\begin{array}{l}\text { Genbank } \\
\text { Numbers }\end{array}$ \\
\hline $\begin{array}{l}\text { Acanthaceae } \\
\text { (Lamiales) }\end{array}$ & $\begin{array}{l}\text { Justicia pectoralis } \\
\text { Jacq. }\end{array}$ & justicia & $\begin{array}{l}\text { Native American } \\
\text { (Rätsch, 2005) }\end{array}$ & $\begin{array}{l}\text { Hallucinogen, antidepressant, } \\
\text { sedative, aphrodisiac (Rätsch, } \\
\text { 2005) }\end{array}$ & AJ879453 \\
\hline $\begin{array}{l}\text { Acoraceae } \\
\text { (Acorales) }\end{array}$ & Acorus calamus L. & sweet flag & $\begin{array}{l}\text { Indomalayan, } \\
\text { Temperate Asian } \\
\text { (Rätsch, 2005) }\end{array}$ & $\begin{array}{l}\text { Stimulant, antidepressant, sedative } \\
\text { (Rätsch, 2005) }\end{array}$ & AJ879453 \\
\hline $\begin{array}{l}\text { Aizoaceae } \\
\text { (Caryophyllales) }\end{array}$ & Sceletium spp. & kougoed & $\begin{array}{l}\text { African and } \\
\text { Middle Eastern } \\
\text { (Gericke \& } \\
\text { Viljoen, 2008) }\end{array}$ & $\begin{array}{l}\text { Sedative, analgesic (Gericke \& } \\
\text { Viljoen, 2008) }\end{array}$ & HM850175 \\
\hline
\end{tabular}




\begin{tabular}{|c|c|c|c|c|c|}
\hline $\begin{array}{l}\text { Apiaceae } \\
\text { (Apiales) }\end{array}$ & $\begin{array}{l}\text { Angelica sinensis } \\
\text { (Oliv.) Diels }\end{array}$ & dong quai & $\begin{array}{l}\text { Temperate Asian } \\
\text { (Rätsch, 2005) }\end{array}$ & $\begin{array}{l}\text { Stimulant, sedative (O’Mahony, } \\
\text { 2010) }\end{array}$ & GQ436632 \\
\hline $\begin{array}{l}\text { Apiaceae } \\
\text { (Apiales) }\end{array}$ & $\begin{array}{l}\text { Centella asiatica } \\
\text { (L) Urb. }\end{array}$ & gotu kola & $\begin{array}{l}\text { Indomalayan, } \\
\text { Temperate Asian } \\
\text { (Rätsch, 2005) }\end{array}$ & $\begin{array}{l}\text { Antianxiety, antidepressant } \\
\text { (Mamedov, 2005) }\end{array}$ & GQ436635 \\
\hline $\begin{array}{l}\text { Apocynaceae } \\
\text { (Gentianales) }\end{array}$ & $\begin{array}{l}\text { Alstonia scholaris } \\
\text { (L.) R. Br. }\end{array}$ & dita & $\begin{array}{l}\text { African and } \\
\text { Middle Eastern, } \\
\text { Australasian, } \\
\text { Indomalayan } \\
\text { (Rätsch, 2005; } \\
\text { Arulmozhi et al., } \\
\text { 2012) }\end{array}$ & $\begin{array}{l}\text { Stimulant, antianxiety, } \\
\text { antidepressant, sedative, analgesic, } \\
\text { aphrodisiac (Rätsch, 2005; } \\
\text { Arulmozhi et al., 2012) }\end{array}$ & EU916739 \\
\hline $\begin{array}{l}\text { Apocynaceae } \\
\text { (Gentianales) }\end{array}$ & $\begin{array}{l}\text { Apocynum } \\
\text { venetum } \mathrm{L}\end{array}$ & luobuma & $\begin{array}{l}\text { Temperate Asian } \\
\text { (Grundmann et al. } \\
\text { 2007) }\end{array}$ & $\begin{array}{l}\text { Antianxiety, antidepressant } \\
\text { (Grundmann et al. 2007; Zheng, } \\
\text { Fan \& Liu, 2013) }\end{array}$ & КР088474 \\
\hline Apocynaceae & Carissa edulis & Arabian & African and & Hallucinogen, aphrodisiac (Rätsch, & JF265327 \\
\hline
\end{tabular}




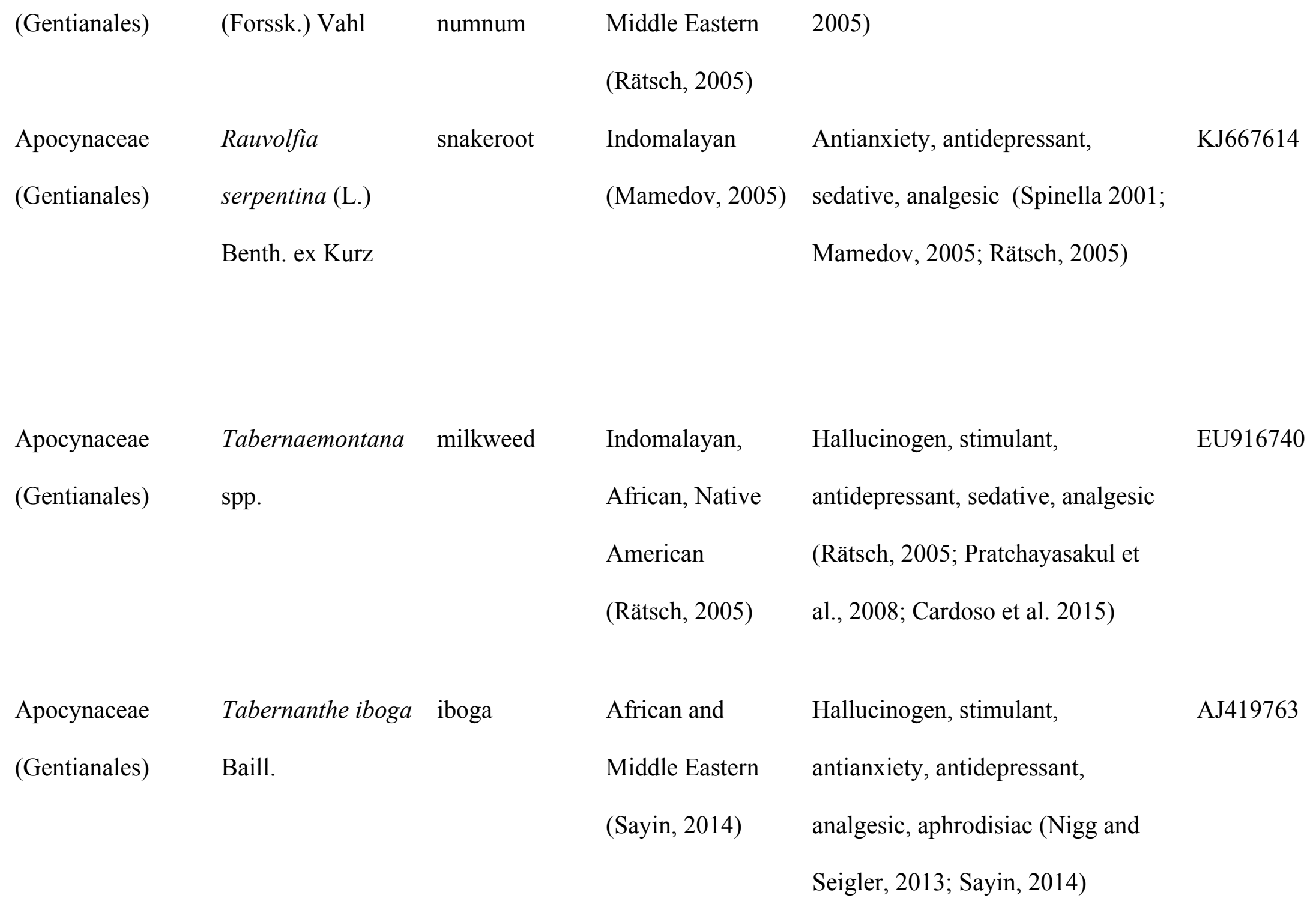




\begin{tabular}{|c|c|c|c|c|c|}
\hline Apocynaceae & Voacanga spp. & voacango & African and & Hallucinogen, stimulant, & KC628529 \\
\hline (Gentianales) & & bush & $\begin{array}{l}\text { Middle Eastern } \\
\text { (Rätsch, 2005) }\end{array}$ & aphrodisiac (Rätsch, 2005) & \\
\hline $\begin{array}{l}\text { Aquifoliaceae } \\
\text { (Aquifoliales) }\end{array}$ & Ilex spp. & yerba mate & $\begin{array}{l}\text { Native American } \\
\text { (Rätsch, 2005) }\end{array}$ & Stimulant (Rätsch, 2005) & FJ394625 \\
\hline $\begin{array}{l}\text { Araliaceae } \\
\text { (Apiales) }\end{array}$ & $\begin{array}{l}\text { Panax ginseng } \\
\text { C.A.Mey. }\end{array}$ & ginseng & $\begin{array}{l}\text { Temperate Asian } \\
\text { (Rätsch, 2005) }\end{array}$ & $\begin{array}{l}\text { Stimulant, antidepressant, } \\
\text { aphrodisiac (Rätsch, 2005) }\end{array}$ & KM088019 \\
\hline $\begin{array}{l}\text { Arecaceae } \\
\text { (Arecales) }\end{array}$ & Areca catechu L. & betel nut & $\begin{array}{l}\text { Indomalayan } \\
\text { (Rätsch, 2005) }\end{array}$ & $\begin{array}{l}\text { Stimulant, sedative, aphrodisiac } \\
\text { (Rätsch, 2005) }\end{array}$ & JX571781 \\
\hline $\begin{array}{l}\text { Asteraceae } \\
\text { (Asterales) }\end{array}$ & Artemisia spp. & wormwood & $\begin{array}{l}\text { European; } \\
\text { Temperate Asian } \\
\text { (Rätsch, 2005; } \\
\text { Sayin, 2014) }\end{array}$ & $\begin{array}{l}\text { Hallucinogen, stimulant, analgesic } \\
\text { aphrodisiac (Rätsch, 2005; Sayin, } \\
\text { 2014) }\end{array}$ & KM360653 \\
\hline $\begin{array}{l}\text { Asteraceae } \\
\text { (Asterales) }\end{array}$ & $\begin{array}{l}\text { Calea ternifolia } \\
\text { Oliv }\end{array}$ & dream herb & $\begin{array}{l}\text { Native American } \\
\text { (Rätsch, 2005) }\end{array}$ & $\begin{array}{l}\text { Hallucinogen, sedative (Rätsch, } \\
\text { 2005) }\end{array}$ & AY215089 \\
\hline
\end{tabular}




\begin{tabular}{|c|c|c|c|c|c|}
\hline Asteraceae & Lactuca virosa & wild lettuce & African and & Sedative, aphrodisiac (Rätsch, & KM360888 \\
\hline (Asterales) & Habl. & & $\begin{array}{l}\text { Middle Eastern } \\
\text { (Rätsch, 2005) }\end{array}$ & 2005) & \\
\hline $\begin{array}{l}\text { Asteraceae } \\
\text { (Asterales) }\end{array}$ & Tagetes spp. & $\begin{array}{l}\text { Mexican } \\
\text { marigold }\end{array}$ & $\begin{array}{l}\text { Native American } \\
\text { (Rätsch, 2005) }\end{array}$ & $\begin{array}{l}\text { Hallucinogen, stimulant, } \\
\text { antianxiety, antidepressant, } \\
\text { aphrodisiac (Rätsch, 2005) }\end{array}$ & AY215184 \\
\hline $\begin{array}{l}\text { Bignoniaceae } \\
\text { (Lamiales) }\end{array}$ & $\begin{array}{l}\text { Bignonia nocturna } \\
\text { (Barb.Rodr.) } \\
\text { L.G.Lohmann } \\
\text { [=Tanaecium } \\
\text { nocturnum } \\
\text { (Barb.Rodr.) } \\
\text { Burea \& } \\
\text { K.Schum.] }\end{array}$ & koribo & $\begin{array}{l}\text { Native American } \\
\text { (Rätsch, 2005). }\end{array}$ & $\begin{array}{l}\text { Sedative, analgesic and aphrodisiac } \\
\text { (Rätsch, 2005). }\end{array}$ & KR534325 \\
\hline $\begin{array}{l}\text { Burseraceae } \\
\text { (Sapindales) }\end{array}$ & $\begin{array}{l}\text { Boswellia sacra } \\
\text { Flueck. }\end{array}$ & olibanum tree & $\begin{array}{l}\text { African and } \\
\text { Middle Eastern }\end{array}$ & Hallucinogen (Rätsch, 2005) & KT934315 \\
\hline
\end{tabular}


(Rätsch, 2005)

\begin{tabular}{|c|c|c|c|c|c|}
\hline Cactaceae & Ariocarpus & chautle & Native American & Hallucinoge, analgesic ((Rätsch, & KC777009 \\
\hline (Caryophyllales) & $\begin{array}{l}\text { fissuratus } \\
\text { (Engelm.) } \\
\text { K.Schum. }\end{array}$ & & (Rätsch, 2005) & 2005; Voogelbreinder 2009) & \\
\hline $\begin{array}{l}\text { Cactaceae } \\
\text { (Caryophyllales) }\end{array}$ & $\begin{array}{l}\text { Echinopsis spp. } \\
\text { (incl. Trichocereus } \\
\text { pachanoi Britton } \\
\text { \& Rose) }\end{array}$ & $\begin{array}{l}\text { San Pedro } \\
\text { cactus }\end{array}$ & $\begin{array}{l}\text { Native American } \\
\text { (Rätsch, 2005) }\end{array}$ & $\begin{array}{l}\text { Hallucinogen, stimulant (Rätsch, } \\
\text { 2005) }\end{array}$ & FR853367 \\
\hline $\begin{array}{l}\text { Cactaceae } \\
\text { (Caryophyllales) }\end{array}$ & $\begin{array}{l}\text { Lophophora } \\
\text { williamsii (Lem. } \\
\text { Ex Salm-Dyck) } \\
\text { J.M. Coult. }\end{array}$ & peyote & $\begin{array}{l}\text { Native American } \\
\text { (Vetulani, 2001) }\end{array}$ & Hallucinogen (Vetulani, 2001) & KC777011 \\
\hline $\begin{array}{l}\text { Cactaceae } \\
\text { (Caryophyllales) }\end{array}$ & Mammillaria spp. & false peyote & $\begin{array}{l}\text { Native America } \\
\text { (Rätsch, 2005) }\end{array}$ & Hallucinogen (Rätsch, 2005) & KC777008 \\
\hline
\end{tabular}




\begin{tabular}{|c|c|c|c|c|c|}
\hline Cactaceae & Pachycereus & pitayo & Native American & Hallucinogen (Schultes, 1976) & JN191499 \\
\hline (Caryophyllales) & $\begin{array}{l}\text { pecten-aboriginum } \\
\text { (Engelm. ex S. } \\
\text { Watson) Britton \& } \\
\text { Rose }\end{array}$ & & (Schultes, 1976) & & \\
\hline $\begin{array}{l}\text { Campanulaceae } \\
\text { (Asterales) }\end{array}$ & Lobelia tupa L. & tupa & $\begin{array}{l}\text { Native American } \\
\text { (Schultes, 1976) }\end{array}$ & $\begin{array}{l}\text { Hallucinogen, sedative (Schultes, } \\
\text { 1976; Rätsch, 2005) }\end{array}$ & EF174606 \\
\hline $\begin{array}{l}\text { Cannabaceae } \\
\text { (Rosales) }\end{array}$ & Cannabis spp. & marijuana & $\begin{array}{l}\text { Indomalayan, } \\
\text { Temperate Asian } \\
\text { (Rätsch, 2005) }\end{array}$ & $\begin{array}{l}\text { Hallucinogen, stimulant, } \\
\text { antianxiety, antidepressant, } \\
\text { sedative, analgesic, aphrodisiac } \\
\text { (Rätsch, 2005) }\end{array}$ & AF500344 \\
\hline $\begin{array}{l}\text { Cannabaceae } \\
\text { (Rosales) }\end{array}$ & $\begin{array}{l}\text { Humulus lupulus } \\
\text { L. }\end{array}$ & hops & $\begin{array}{l}\text { European } \\
\text { (Rätsch, 2005) }\end{array}$ & $\begin{array}{l}\text { Antianxiety, sedative (Heinrich et } \\
\text { al. 2012; McCall et al., 2013) }\end{array}$ & KT266264 \\
\hline $\begin{array}{l}\text { Caprifoliaceae } \\
\text { (Dipsacales) }\end{array}$ & $\begin{array}{l}\text { Nardostachys } \\
\text { jatamansi (D. } \\
\text { Don) DC. }\end{array}$ & jatamansi & $\begin{array}{l}\text { Indomalaya } \\
\text { (Chaudhary et al. } \\
\text { 2015) }\end{array}$ & $\begin{array}{l}\text { Antidepressant, sedative } \\
\text { (Chaudhary et al. 2015) }\end{array}$ & AF446950 \\
\hline
\end{tabular}




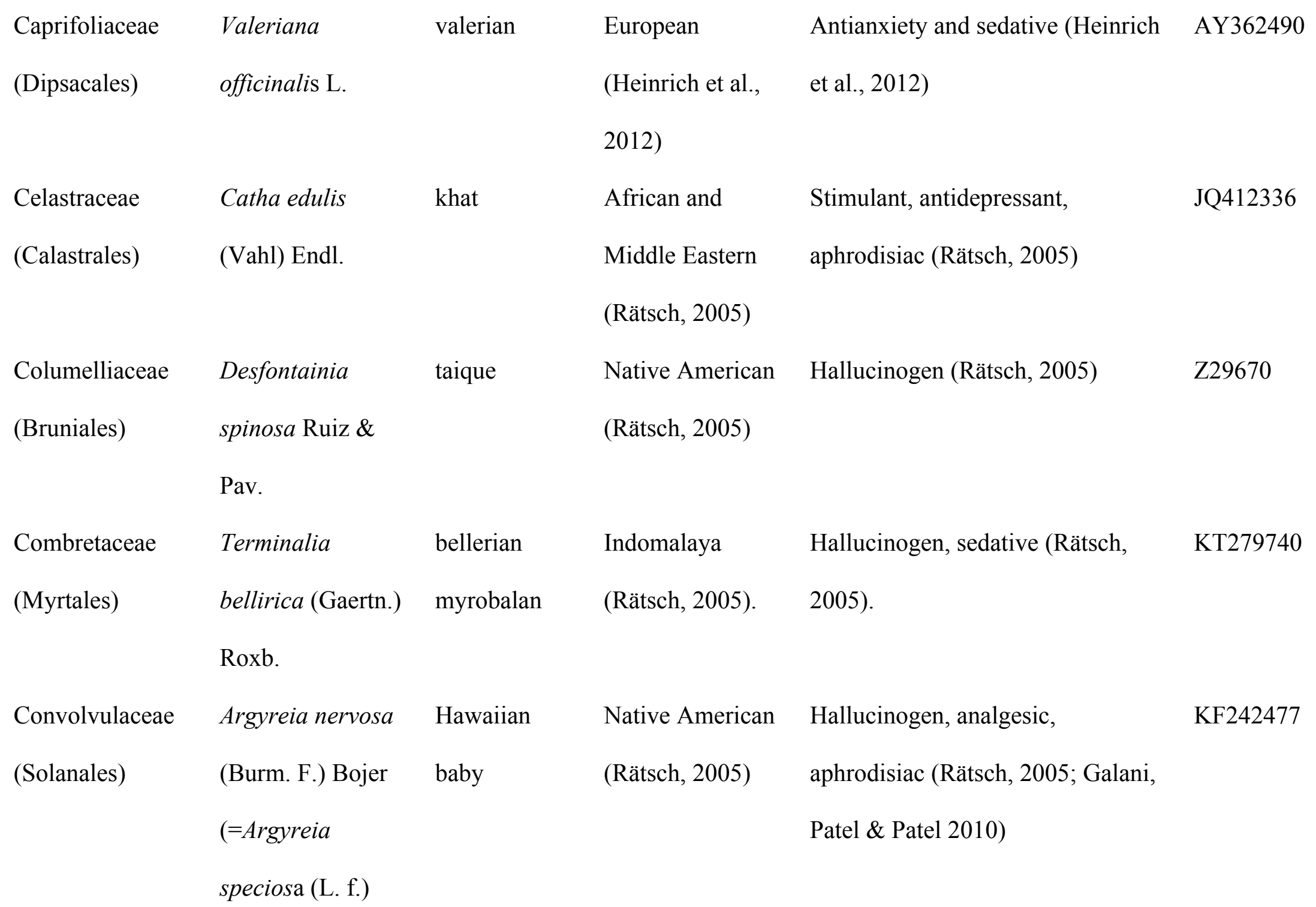


Sweet)

\begin{tabular}{|c|c|c|c|c|c|}
\hline Convolvulaceae & Convolvulus & dwart & European & Sedative, analgesic (Rätsch, 2005) & L11683 \\
\hline (Solanales) & tricolor L. & morning glory & (Rätsch, 2005) & & \\
\hline $\begin{array}{l}\text { Convolvulaceae } \\
\text { (Solanales) }\end{array}$ & Ipomoea spp. & morning glory & $\begin{array}{l}\text { Native American } \\
\text { (Rätsch, 2005) }\end{array}$ & $\begin{array}{l}\text { Hallucinogen, stimulant, } \\
\text { aphrodisiac (Rätsch, 2005; Meira et } \\
\text { al. 2012) }\end{array}$ & KF242478 \\
\hline $\begin{array}{l}\text { Convolvulaceae } \\
\text { (Solanales) }\end{array}$ & $\begin{array}{l}\text { Turbina } \\
\text { corymbosa }(\mathrm{L} .) \\
\text { Raf. }\end{array}$ & ololiuqui vine & $\begin{array}{l}\text { Native American } \\
\text { (Rätsch, 2005). }\end{array}$ & $\begin{array}{l}\text { Hallucinogen, analgesic (Rätsch, } \\
\text { 2005). }\end{array}$ & AY100966 \\
\hline $\begin{array}{l}\text { Cupressaceae } \\
\text { (Pinales) }\end{array}$ & $\begin{array}{l}\text { Juniperus recurva } \\
\text { Buch.-Ham. ex D. }\end{array}$ & $\begin{array}{l}\text { Himalayan } \\
\text { weeping }\end{array}$ & $\begin{array}{l}\text { Indomalayan, } \\
\text { Temperate Asian }\end{array}$ & Hallucinogen (Rätsch, 2005) & JQ512552 \\
\hline & Don & juniper & (Rätsch, 2005) & & \\
\hline $\begin{array}{l}\text { Ephedraceae } \\
\text { (Ephedrales) }\end{array}$ & Ephedra spp. & ephedra & $\begin{array}{l}\text { Temperate Asian } \\
\text { (Heinrich et al., } \\
\text { 2012) }\end{array}$ & Stimulant (Rätsch, 2005) & AY056562 \\
\hline
\end{tabular}




\begin{tabular}{|c|c|c|c|c|c|}
\hline $\begin{array}{l}\text { Ericaceae } \\
\text { (Ericales) }\end{array}$ & Ledum palustre L. & wild rosemary & $\begin{array}{l}\text { Temperate Asian } \\
\text { (Rätsch, 2005) }\end{array}$ & $\begin{array}{l}\text { Hallucinogen, sedative, analgesic } \\
\text { (Rätsch, 2005) }\end{array}$ & AF419831 \\
\hline $\begin{array}{l}\text { Ericaceae } \\
\text { (Ericales) }\end{array}$ & $\begin{array}{l}\text { Rhododendron } \\
\text { molle G.Don. }\end{array}$ & yang zhi zhu & $\begin{array}{l}\text { Temperate Asian } \\
\text { (Mamedov, 2005) }\end{array}$ & Antidepressant (Mamedov, 2005) & AF421101 \\
\hline $\begin{array}{l}\text { Erythroxylaceae } \\
\text { (Malpighiales) }\end{array}$ & Erythroxylum spp. & Coca & $\begin{array}{l}\text { Native American } \\
\text { (Rätsch, 2005). }\end{array}$ & $\begin{array}{l}\text { Stimulant, antianxiety, analgesic } \\
\text { and aphrodisiac (Rätsch, 2005) }\end{array}$ & AB925614 \\
\hline $\begin{array}{l}\text { Fabaceae } \\
\text { (Fabales) }\end{array}$ & Acacia spp. & wattle & $\begin{array}{l}\text { African/Middle } \\
\text { Eastern } \\
\text { Australasian, } \\
\text { Indomalayan, } \\
\text { Native American, } \\
\text { (Rätsch, 2005) }\end{array}$ & $\begin{array}{l}\text { Hallucinogen, aphrodisiac (Rätsch, } \\
\text { 2005) }\end{array}$ & HM849736 \\
\hline $\begin{array}{l}\text { Fabaceae } \\
\text { (Fabales) }\end{array}$ & $\begin{array}{l}\text { Anadenanthera } \\
\text { spp. }\end{array}$ & vilca, yopo & $\begin{array}{l}\text { Native American } \\
\text { (Rätsch, 2005) }\end{array}$ & $\begin{array}{l}\text { Hallucinogen and analgesic } \\
\text { (Schultes, 1976) }\end{array}$ & KJ082119 \\
\hline Fabaceae & Astragalus spp. & milk vetch & Native America & Hallucinogen (Rätsch, 2005) & KU666554 \\
\hline
\end{tabular}


(Fabales)

Fabacea

(Fabales)

Fabaceae

(Fabales)

Fabaceae

(Fabales)

Fabaceae

(Fabales)

Fabaceae

(Fabales)
(Rätsch, 2005)

\section{Calliandra}

cabellito

Native American

Hallucinogen and analgesic

AM234255

anomala (Kunth)

(Rätsch, 2005) （Rätsch, 2005)

J.F. Macbr.

\section{Desmanthus}

illinoensis

prairie bundle

Native American

Hallucinogen (Halpern, 2004)

KP126868

flower

(Halpern, 2004)

(Michx.) MacMill.

Erythrina spp.

coral trees

Native American,

Hallucinogen and sedative (Rätsch,

AB045801

Indomalaya 2005).

(Rätsch, 2005).

\section{Lonchocarpus}

balche' tree

Native American

Hallucinogen (Rätsch, 2005)

JQ626245

violaceus Benth.

Mimosa spp.

mimosa
(Rätsch, 2005)

Native American,

Indomalayan

aphrodisiac (Rätsch, 2005)

(Rätsch, 2005) 


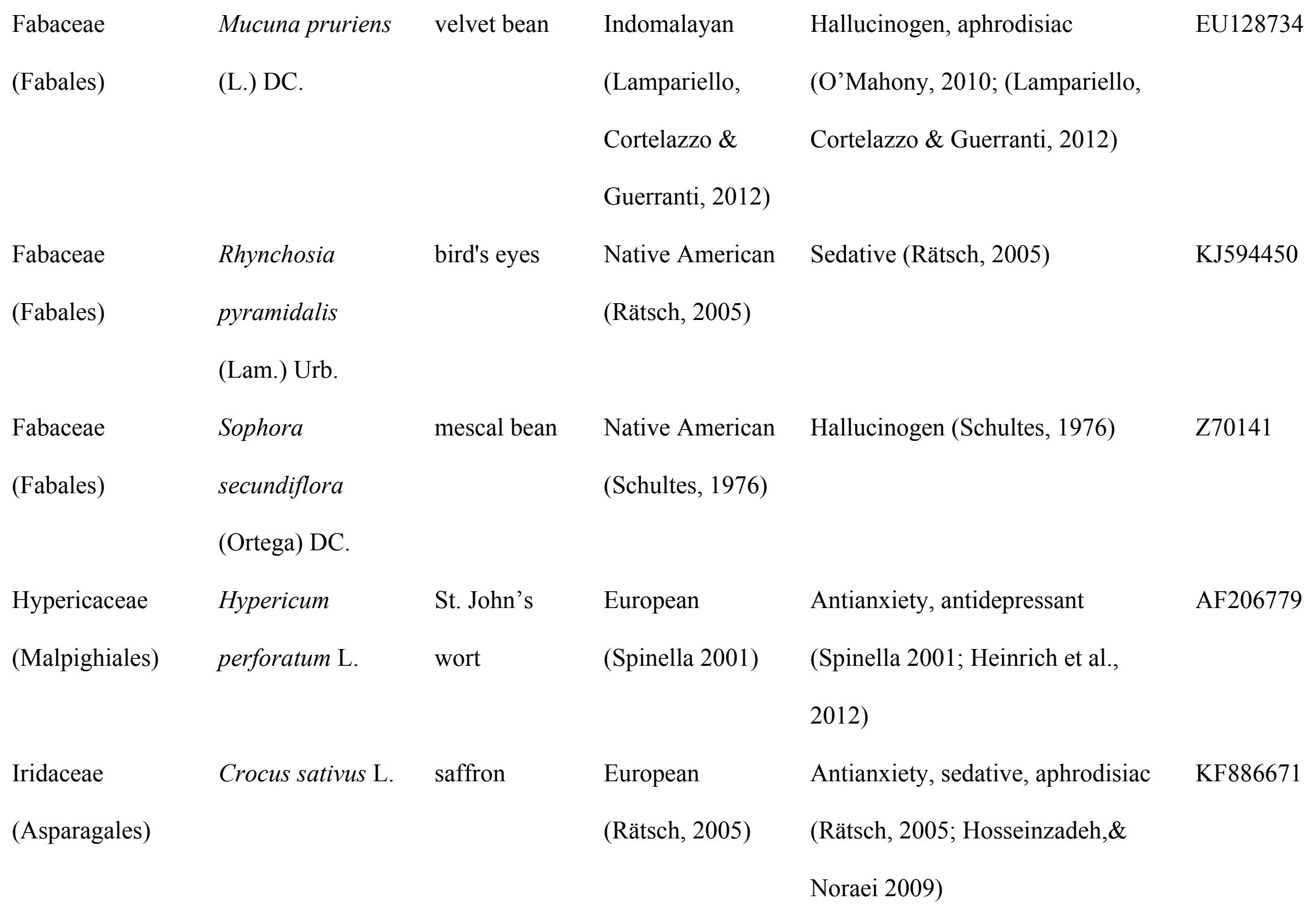




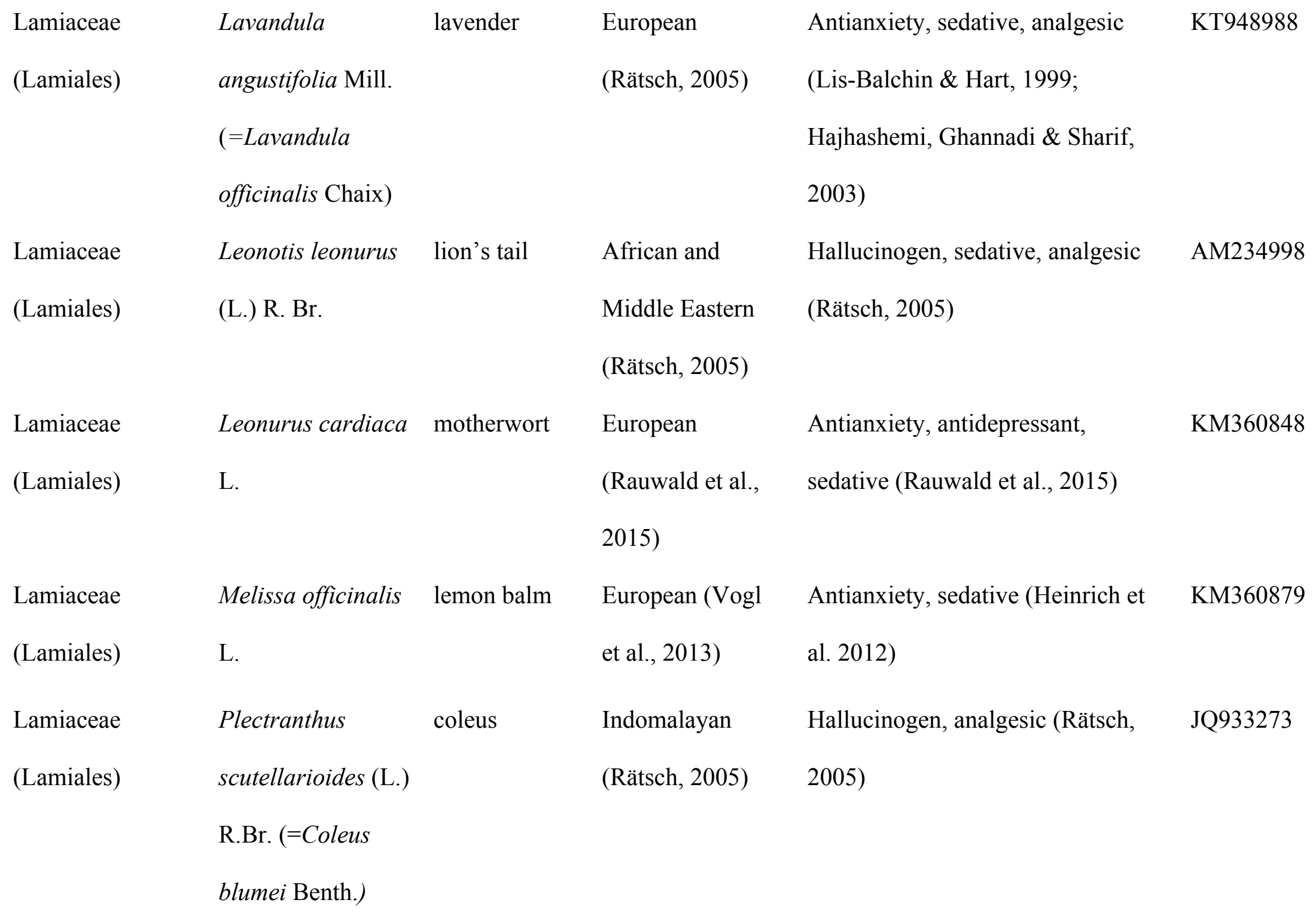




\begin{tabular}{|c|c|c|c|c|c|}
\hline Lamiaceae & Rosmarinus & rosemary & European & Antianxiety, antidepressant, & KR232566 \\
\hline (Lamiales) & officinalis L. & & $\begin{array}{l}\text { (Ferlemi et al. } \\
\text { 2015) }\end{array}$ & analgesic (Ferlemi et al. 2015 & \\
\hline $\begin{array}{l}\text { Lamiaceae } \\
\text { (Lamiales) }\end{array}$ & $\begin{array}{l}\text { Salvia divinorum } \\
\text { Epling \& Jativa }\end{array}$ & $\begin{array}{l}\text { yerba de la } \\
\text { pastora }\end{array}$ & $\begin{array}{l}\text { Native American } \\
\text { (Rätsch, 2005) }\end{array}$ & $\begin{array}{l}\text { Hallucinogen, analgesic (Rätsch, } \\
\text { 2005) }\end{array}$ & AY570410 \\
\hline $\begin{array}{l}\text { Lamiaceae } \\
\text { (Lamiales) }\end{array}$ & $\begin{array}{l}\text { Scutellaria } \\
\text { lateriflora L. }\end{array}$ & skullcap & $\begin{array}{l}\text { Native American } \\
\text { (Awad et al., } \\
\text { 2003) }\end{array}$ & $\begin{array}{l}\text { Antianxiety, sedative (Awad et al., } \\
\text { 2003) }\end{array}$ & HQ590266 \\
\hline $\begin{array}{l}\text { Lauraceae } \\
\text { (Laurales) }\end{array}$ & $\begin{array}{l}\text { Cinnamomum } \\
\text { camphora (L.) J. } \\
\text { Presl }\end{array}$ & camphor & $\begin{array}{l}\text { Indomalayan, } \\
\text { Temperate Asian } \\
\text { (Rätsch, 2005) }\end{array}$ & Stimulant, sedative, (Rätsch, 2005) & L12641 \\
\hline $\begin{array}{l}\text { Lauraceae } \\
\text { (Laurales) }\end{array}$ & $\begin{array}{l}\text { Sassafras albidum } \\
\text { (Nutt.) Nees }\end{array}$ & sassafras & $\begin{array}{l}\text { Native American } \\
\text { (Rätsch, 2005) }\end{array}$ & Stimulant (Rätsch, 2005) & AF206819 \\
\hline $\begin{array}{l}\text { Loganiaceae } \\
\text { (Gentianales) }\end{array}$ & $\begin{array}{l}\text { Strychnos nux- } \\
\text { vomica } \mathrm{L} \text {. }\end{array}$ & $\begin{array}{l}\text { strychnine } \\
\text { tree }\end{array}$ & $\begin{array}{l}\text { Indomalaya } \\
\text { (Rätsch, 2005) }\end{array}$ & $\begin{array}{l}\text { Stimulant, antianxiety, } \\
\text { antidepressant, aphrodisiac (Rätsch, } \\
\text { 2005) }\end{array}$ & L14410 \\
\hline
\end{tabular}




\begin{tabular}{|c|c|c|c|c|c|}
\hline $\begin{array}{l}\text { Lythraceae } \\
\text { (Myrtales) }\end{array}$ & $\begin{array}{l}\text { Heimia salicifolia } \\
\text { (Kunth) Link }\end{array}$ & sinicuiche & $\begin{array}{l}\text { Native American } \\
\text { (Rätsch, 2005) }\end{array}$ & $\begin{array}{l}\text { Hallucinogen, sedative (Rätsch, } \\
\text { 2005) }\end{array}$ & AY905410 \\
\hline $\begin{array}{l}\text { Malpighiaceae } \\
\text { (Malpighiales) }\end{array}$ & Banisteriopsis spp. & ayahuasca & $\begin{array}{l}\text { Native American } \\
\text { (Sayin, 2014) }\end{array}$ & Hallucinogen (Sayin, 2014) & HQ247440 \\
\hline $\begin{array}{l}\text { Malpighiaceae } \\
\text { (Malpighiales) }\end{array}$ & $\begin{array}{l}\text { Diplopterys } \\
\text { cabrerana } \\
\text { (Cuatrec) B. Gates }\end{array}$ & chaliponga & $\begin{array}{l}\text { Native American } \\
\text { (Sayin, 2014) }\end{array}$ & Hallucinogen (O’Mahony, 2010). & HQ247482 \\
\hline $\begin{array}{l}\text { Malvaceae } \\
\text { (Malvales) }\end{array}$ & Cola spp. & kola nut & $\begin{array}{l}\text { Africa and } \\
\text { Middle Eastern } \\
\text { (McClatchey et } \\
\text { al., 2009) }\end{array}$ & Stimulant (McClatchey et al., 2009) & AY082353 \\
\hline $\begin{array}{l}\text { Malvaceae } \\
\text { (Malvales) }\end{array}$ & Sida acuta Burm.f. & broomweed & $\begin{array}{l}\text { Native America } \\
\text { (Rätsch, 2005) }\end{array}$ & Stimulant (Rätsch, 2005) & KJ773888 \\
\hline $\begin{array}{l}\text { Malvaceae } \\
\text { (Malvales) }\end{array}$ & Theobroma spp. & cacao & $\begin{array}{l}\text { Native American } \\
\text { (Rätsch, 2005). }\end{array}$ & Stimulant (Rätsch, 2005). & JQ228389 \\
\hline Malvaceae & Tilia spp. & linden & European & Antianxiety, sedative (Rätsch, & KT894775 \\
\hline
\end{tabular}


(Malvales)

(Rätsch, 2005)

\begin{tabular}{|c|c|c|c|c|c|}
\hline $\begin{array}{l}\text { Melanthiaceae } \\
\text { (Liliales) }\end{array}$ & Veratrum album L. & $\begin{array}{l}\text { white } \\
\text { hellebore }\end{array}$ & $\begin{array}{l}\text { European } \\
\text { (Rätsch, 2005) }\end{array}$ & Hallucinogen (Rätsch, 2005) & KM242984 \\
\hline $\begin{array}{l}\text { Myristicaceae } \\
\text { (Magnoliales) }\end{array}$ & $\begin{array}{l}\text { Horsfieldia } \\
\text { australiana S. T. } \\
\text { Blake }\end{array}$ & nutmeg & $\begin{array}{l}\text { Australasian, } \\
\text { (Rätsch, 2005) }\end{array}$ & Hallucinogen (Rätsch, 2005) & KF496315 \\
\hline $\begin{array}{l}\text { Myristicaceae } \\
\text { (Magnoliales) }\end{array}$ & $\begin{array}{l}\text { Myristica fragrans } \\
\text { Houtt. }\end{array}$ & nutmeg & $\begin{array}{l}\text { Australiasia, } \\
\text { Indomalaya } \\
\text { (Rätsch, 2005) }\end{array}$ & $\begin{array}{l}\text { Hallucinogen, stimulant, sedative } \\
\text { aprhodisiac (Rätsch, 2005) }\end{array}$ & AF206798 \\
\hline $\begin{array}{l}\text { Myristicaceae } \\
\text { (Magnoliales) }\end{array}$ & $\begin{array}{l}\text { Osteophloeum } \\
\text { platyspermum } \\
\text { (Spruce ex A.DC.) } \\
\text { Warb. }\end{array}$ & huapa & $\begin{array}{l}\text { Native American } \\
\text { (Rätsch, 2005) }\end{array}$ & Hallucinogen (Rätsch, 2005) & JQ625884 \\
\hline $\begin{array}{l}\text { Myristicaceae } \\
\text { (Magnoliales) }\end{array}$ & $\begin{array}{l}\text { Virola elongata } \\
\text { (Benth.) Warb. }\end{array}$ & epena & $\begin{array}{l}\text { Native American } \\
\text { (Rätsch, 2005) }\end{array}$ & $\begin{array}{l}\text { Hallucinogen, stimulant (Rätsch, } \\
\text { 2005) }\end{array}$ & JQ626043 \\
\hline
\end{tabular}




\begin{tabular}{|c|c|c|c|c|c|}
\hline Myrtaceae & Psidium guajava & guava & African and & Sedative, analgesic (Rätsch, 2005) & JQ025077 \\
\hline (Myrtales) & L. & & $\begin{array}{l}\text { Middl eastern } \\
\text { (Rätsch, 2005) }\end{array}$ & & \\
\hline $\begin{array}{l}\text { Nitrariaceae } \\
\text { (Sapindales) }\end{array}$ & $\begin{array}{l}\text { Peganum harmala } \\
\text { L. }\end{array}$ & harmal & $\begin{array}{l}\text { African and } \\
\text { Middle Eastern } \\
\text { (Sayin, 2014) }\end{array}$ & $\begin{array}{l}\text { Hallucinogen, stimulant, analgesic } \\
\text { (Vetulani, 2001; Farouk et al., } \\
\text { 2008) }\end{array}$ & DQ267164 \\
\hline $\begin{array}{l}\text { Nymphaeaceae } \\
\text { (Nymphaeales) }\end{array}$ & $\begin{array}{l}\text { Nuphar lutea (L.) } \\
\text { Sm. }\end{array}$ & $\begin{array}{l}\text { yellow water } \\
\text { lily }\end{array}$ & $\begin{array}{l}\text { European } \\
\text { (Rätsch, 2005) }\end{array}$ & Sedative (Rätsch, 2005) & DQ182338 \\
\hline $\begin{array}{l}\text { Nymphaeaceae } \\
\text { (Nymphaeales) }\end{array}$ & Nymphaea spp. & water lily & $\begin{array}{l}\text { African and } \\
\text { Middle eastern } \\
\text { (Rätsch, 2005) }\end{array}$ & Sedative (Rätsch, 2005) & GQ468660 \\
\hline $\begin{array}{l}\text { Olacaceae } \\
\text { (Santalales) }\end{array}$ & $\begin{array}{l}\text { Ptychopetalum } \\
\text { olacoides Benth. }\end{array}$ & marapuama & $\begin{array}{l}\text { Native American } \\
\text { (Piato et al., } \\
\text { 2008) }\end{array}$ & $\begin{array}{l}\text { Stimulant, Antidepressant (Piato et } \\
\text { al., 2008) }\end{array}$ & FJ038139 \\
\hline $\begin{array}{l}\text { Orchidaceae } \\
\text { (Asparagales) }\end{array}$ & $\begin{array}{l}\text { Vanilla planifolia } \\
\text { Jacks. ex Andrews }\end{array}$ & vanilla & $\begin{array}{l}\text { Native America } \\
\text { (Rätsch, 2005) }\end{array}$ & $\begin{array}{l}\text { Stimulant, sedative, aphrodisiac } \\
\text { (Rätsch, 2005; O’Mahony, 2010) }\end{array}$ & KJ566306 \\
\hline
\end{tabular}




\begin{tabular}{|c|c|c|c|c|c|}
\hline Orobanchaceae & Cistanche & rou cong rong & Temperate Asian & Stimulant, aphrodisiac (O’Mahony, & KC128846 \\
\hline (Lamiales) & deserticola & & (Wang, Zhang \& & 2010) & \\
\hline & K.C.Ma & & Xie, 2012) & & \\
\hline $\begin{array}{l}\text { Pandanaceae } \\
\text { (Pandanales) }\end{array}$ & Pandanus spp. & screwpine & $\begin{array}{l}\text { Australasian } \\
\text { (Rätsch, 2005) }\end{array}$ & $\begin{array}{l}\text { Hallucinoge, analgesic ((Rätsch, } \\
\text { 2005) }\end{array}$ & JX903247 \\
\hline $\begin{array}{l}\text { Papaveraceae } \\
\text { (Ranunculales) }\end{array}$ & $\begin{array}{l}\text { Argemone } \\
\text { mexicana L. }\end{array}$ & $\begin{array}{l}\text { Mexican } \\
\text { poppy }\end{array}$ & $\begin{array}{l}\text { Native American } \\
\text { (Rätsch, 2005) }\end{array}$ & $\begin{array}{l}\text { Hallucinogen, sedative, analgesic, } \\
\text { aphrodisiac (Rätsch, 2005; } \\
\text { Brahmachari, Gorai \& Roy, 2013) }\end{array}$ & U86621 \\
\hline $\begin{array}{l}\text { Papaveraceae } \\
\text { (Ranunculales) }\end{array}$ & $\begin{array}{l}\text { Eschscholzia } \\
\text { californica Cham. }\end{array}$ & $\begin{array}{l}\text { California } \\
\text { poppy }\end{array}$ & $\begin{array}{l}\text { Native American } \\
\text { (Rolland et al., } \\
\text { 1991) }\end{array}$ & $\begin{array}{l}\text { Antianxiety, sedative, analgesic } \\
\text { (Rolland et al., 1991) }\end{array}$ & KM360775 \\
\hline $\begin{array}{l}\text { Papaveraceae } \\
\text { (Ranunculales) }\end{array}$ & $\begin{array}{l}\text { Meconopsis } \\
\text { horridula Hook. f. }\end{array}$ & $\begin{array}{l}\text { prickly blue } \\
\text { poppy }\end{array}$ & $\begin{array}{l}\text { Temperate Asian } \\
\text { (Fan et al., 2015) }\end{array}$ & $\begin{array}{l}\text { Sedative, analgesic (Fan et al., } \\
2015 \text { ) }\end{array}$ & JX087717 \\
\hline
\end{tabular}




\begin{tabular}{|c|c|c|c|c|c|}
\hline Papaveraceae & Papaver & opium poppy & African and & Hallucinogen, sedative, analgesic, & KU204905 \\
\hline (Ranunculales) & somniferum $\mathrm{L}$. & & $\begin{array}{l}\text { Middle Eastern } \\
\text { (Vetulani, 2001) }\end{array}$ & aphrodisiac (Rätsch, 2005) & \\
\hline $\begin{array}{l}\text { Passifloraceae } \\
\text { (Malpighiales) }\end{array}$ & Passiflora spp. & $\begin{array}{l}\text { passion } \\
\text { flower }\end{array}$ & $\begin{array}{l}\text { Native American } \\
\text { (Rätsch, 2005) }\end{array}$ & $\begin{array}{l}\text { Antianxiety, sedative (Heinrich et } \\
\text { al. 2012) }\end{array}$ & HQ900864 \\
\hline $\begin{array}{l}\text { Passifloraceae } \\
\text { (Malpighiales) }\end{array}$ & $\begin{array}{l}\text { Turnera diffusa } \\
\text { Willd. ex Schult. }\end{array}$ & damiana & $\begin{array}{l}\text { Native American } \\
\text { (Rätsch, 2005) }\end{array}$ & $\begin{array}{l}\text { Stimulant, antianxiety, aphrodisiac } \\
\text { (Rätsch, 2005) }\end{array}$ & JQ593109 \\
\hline $\begin{array}{l}\text { Phytolaccaceae } \\
\text { (Caryophyllales) }\end{array}$ & $\begin{array}{l}\text { Phytolacca } \\
\text { acinosa Roxb. }\end{array}$ & pokeweed & $\begin{array}{l}\text { Temperate Asian } \\
\text { (Rätsch, 2005) }\end{array}$ & Hallucinogen (Rätsch, 2005) & HM850257 \\
\hline $\begin{array}{l}\text { Piperaceae } \\
\text { (Piperales) }\end{array}$ & Arundo donax L. & giant reed & $\begin{array}{l}\text { African and } \\
\text { Middle Eastern; } \\
\text { Native American } \\
\text { (Rätsch, 2005) }\end{array}$ & Hallucinogen (Rätsch, 2005) & U13226 \\
\hline $\begin{array}{l}\text { Piperaceae } \\
\text { (Piperales) }\end{array}$ & Piper spp. & pepper, kava & $\begin{array}{l}\text { Native American, } \\
\text { Indomalayan, } \\
\text { Australasian }\end{array}$ & $\begin{array}{l}\text { Stimulant, antianxiety, sedative, } \\
\text { analgesic, aphrodisiac (Rätsch, } \\
\text { 2005) }\end{array}$ & AY032642 \\
\hline
\end{tabular}


(Rätsch, 2005)

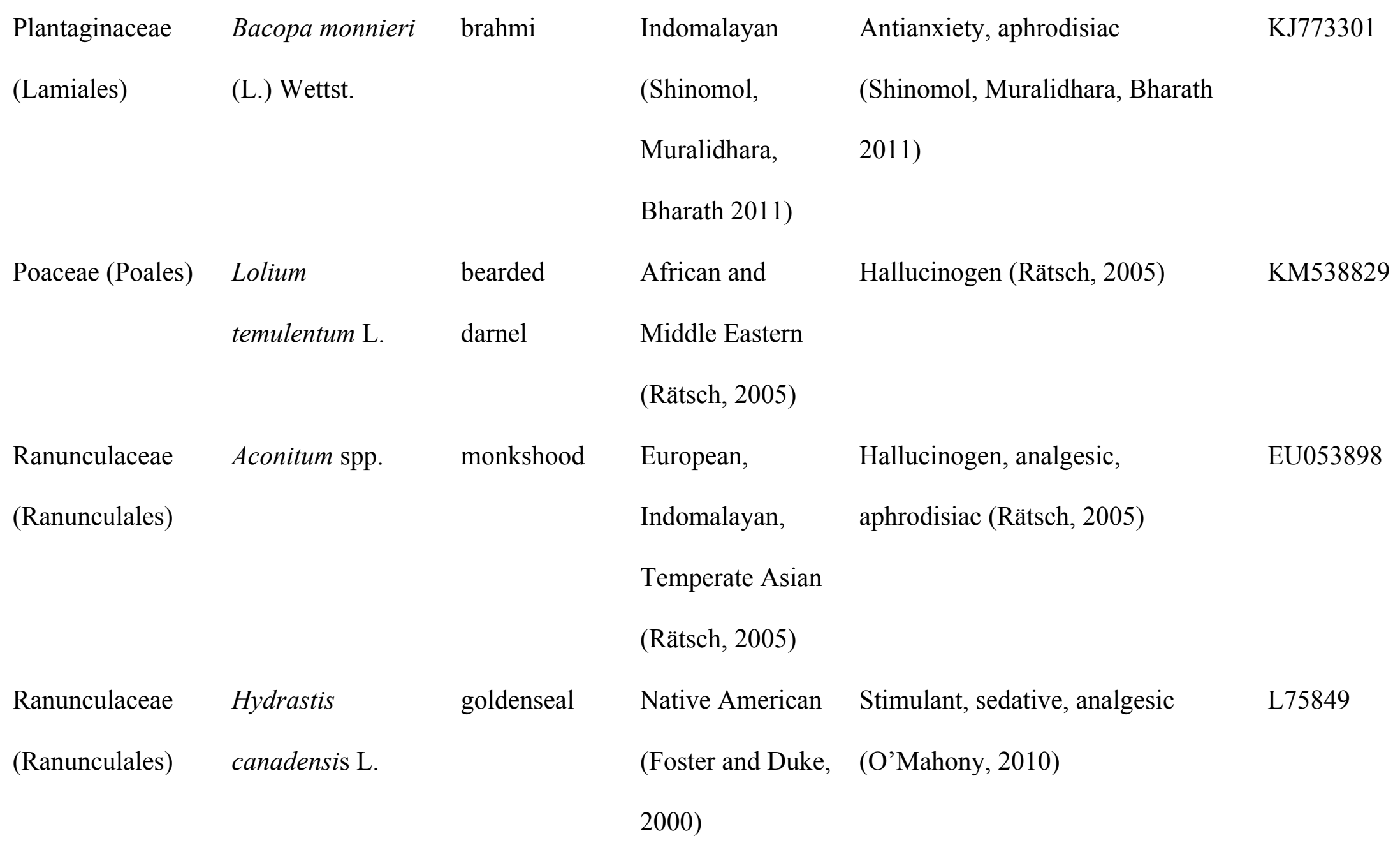




\begin{tabular}{|c|c|c|c|c|c|}
\hline Rubiaceae & Catunaregam & chibra & Africa and & Antianxiety, antidepressant & AJ286700 \\
\hline (Gentianales) & $\begin{array}{l}\text { nilotica (Stapf) } \\
\text { Tirveng. (=Randia } \\
\text { nilotica } \text { Stapf) }\end{array}$ & & $\begin{array}{l}\text { Middle eastern } \\
\text { (Danjuma et al. } \\
\text { 2014) }\end{array}$ & (Danjuma et al. 2014) & \\
\hline $\begin{array}{l}\text { Rubiaceae } \\
\text { (Gentianales) }\end{array}$ & Coffea arabica L. & coffee & $\begin{array}{l}\text { African and } \\
\text { Middle Eastern } \\
\text { (Rätsch, 2005) }\end{array}$ & Stimulant (Rätsch, 2005) & EF044213 \\
\hline $\begin{array}{l}\text { Rubiaceae } \\
\text { (Gentianales) }\end{array}$ & Corynanthe spp. & pamprama & $\begin{array}{l}\text { African and } \\
\text { Middle Eastern } \\
\text { (Rätsch, 2005) }\end{array}$ & $\begin{array}{l}\text { Stimulant and aphrodisiac (Rätsch, } \\
\text { 2005) }\end{array}$ & AJ346977 \\
\hline $\begin{array}{l}\text { Rubiaceae } \\
\text { (Gentianales) }\end{array}$ & $\begin{array}{l}\text { Mitragyna } \\
\text { speciosa (Korth.) } \\
\text { Havil }\end{array}$ & kratom & $\begin{array}{l}\text { Indomalaya } \\
\text { (Idayu et al, 2011; } \\
\text { Suhaimi et al. } \\
\text { 2016) }\end{array}$ & $\begin{array}{l}\text { Stimulant, analgesic, sedative, } \\
\text { (Rätsch, 2005; Suhaimi et al. 2016) }\end{array}$ & AJ346988 \\
\hline $\begin{array}{l}\text { Rubiaceae } \\
\text { (Gentianales) }\end{array}$ & $\begin{array}{l}\text { Pausinystalia } \\
\text { johimbe }\end{array}$ & yohimbe & $\begin{array}{l}\text { African and } \\
\text { Middle Eastern }\end{array}$ & $\begin{array}{l}\text { Hallucinogen, stimulant, } \\
\text { antidepressant, aphrodisiac (Rätsch, }\end{array}$ & AJ346998 \\
\hline
\end{tabular}


(K.Schum.) Pierre

ex Beille

Rubiaceae

(Gentianales)

Santalaceae

(Santalales)

Sapindaceae

(Sapindales)

Solanaceae

(Solanales)

Solanaceae

(Solanales)

$$
\text { Psychotria spp. }
$$

Gardner

Paullinia spp.
(Rätsch, 2005)

chacruna

Native American

Hallucinogen, sedative, analgesic

KJ805654

(Rätsch, 2005) （Rätsch, 2005)

sandalwood

Australasian

Sedative (Rätsch, 2005)

L26077

(Rätsch, 2005)

guarana

Native American

Stimulant (McClatchey et al., 2009)

AY724365

(McClatchey et

al., 2009)

Atropa belladonna

belladonna

European

Hallucinogen, stimulant, sedative

AJ316582

(Schultes, 1976) aphrodisiac (Rätsch, 2005)

Native American

Hallucinogen, sedative, aphrodisiac

HM849829
(Rätsch, 2005)

(Rätsch, 2005) 


\begin{tabular}{|c|c|c|c|c|c|}
\hline $\begin{array}{l}\text { Solanaceae } \\
\text { (Solanales) }\end{array}$ & Brunfelsia spp. & raintree & $\begin{array}{l}\text { Native American } \\
\text { (Rätsch, 2005) }\end{array}$ & $\begin{array}{l}\text { Hallucinogen, analgesic (Rätsch, } \\
\text { 2005) }\end{array}$ & AY206720 \\
\hline $\begin{array}{l}\text { Solanaceae } \\
\text { (Solanales) }\end{array}$ & Cestrum spp. & $\begin{array}{l}\text { flowering } \\
\text { jessamine }\end{array}$ & $\begin{array}{l}\text { Native American } \\
\text { (Rätsch, 2005) }\end{array}$ & $\begin{array}{l}\text { Hallucinogen, sedative, analgesic } \\
\text { (Rätsch, 2005) }\end{array}$ & JX572398 \\
\hline $\begin{array}{l}\text { Solanaceae } \\
\text { (Solanales) }\end{array}$ & Datura spp. & toloache & $\begin{array}{l}\text { Native American, } \\
\text { Indomalayan, } \\
\text { European } \\
\text { (Rätsch, 2005) }\end{array}$ & $\begin{array}{l}\text { Hallucinogen, sedative, analgesic, } \\
\text { aphrodisiac (Rätsch, 2005) }\end{array}$ & JX996059 \\
\hline $\begin{array}{l}\text { Solanaceae } \\
\text { (Solanales) }\end{array}$ & Duboisia spp. & pituri & $\begin{array}{l}\text { Australasian } \\
\text { (Rätsch, 2005) }\end{array}$ & $\begin{array}{l}\text { Hallucinogen, stimulant, } \\
\text { aphrodisiac (Rätsch, 2005) }\end{array}$ & KM895868 \\
\hline $\begin{array}{l}\text { Solanaceae } \\
\text { (Solanales) }\end{array}$ & Hyoscyamus spp. & Henbane & $\begin{array}{l}\text { European } \\
\text { (Rätsch, 2005) }\end{array}$ & $\begin{array}{l}\text { Hallucinogen. sedative (Rätsch, } \\
\text { 2005) }\end{array}$ & KF248009 \\
\hline $\begin{array}{l}\text { Solanaceae } \\
\text { (Solanales) }\end{array}$ & $\begin{array}{l}\text { Iochroma } \\
\text { fuchsioides } \\
\text { (Bonpl.) Miers }\end{array}$ & yas & $\begin{array}{l}\text { Native American } \\
\text { (Rätsch, 2005) }\end{array}$ & Sedative (Rätsch, 2005) & KU310432 \\
\hline
\end{tabular}




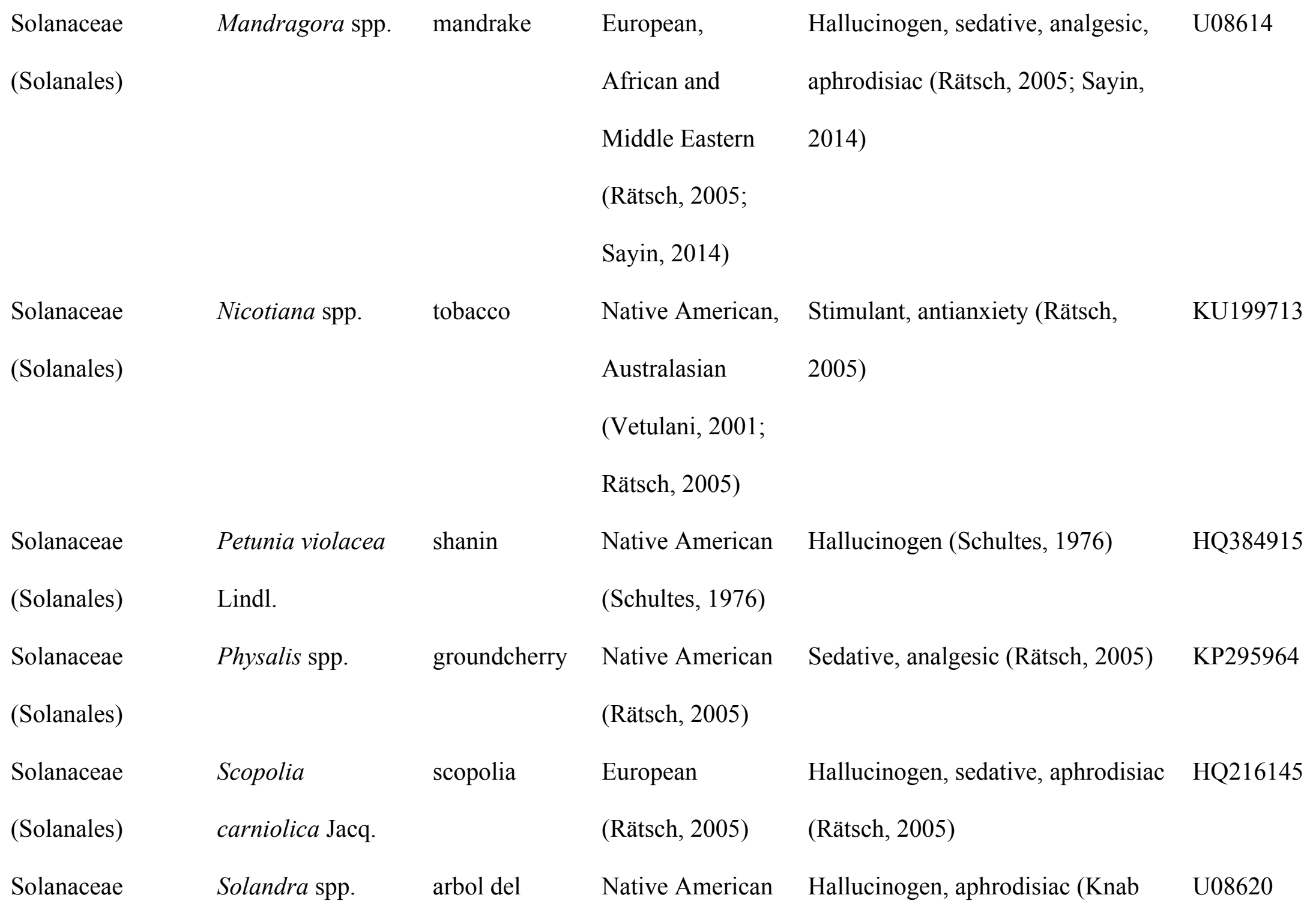




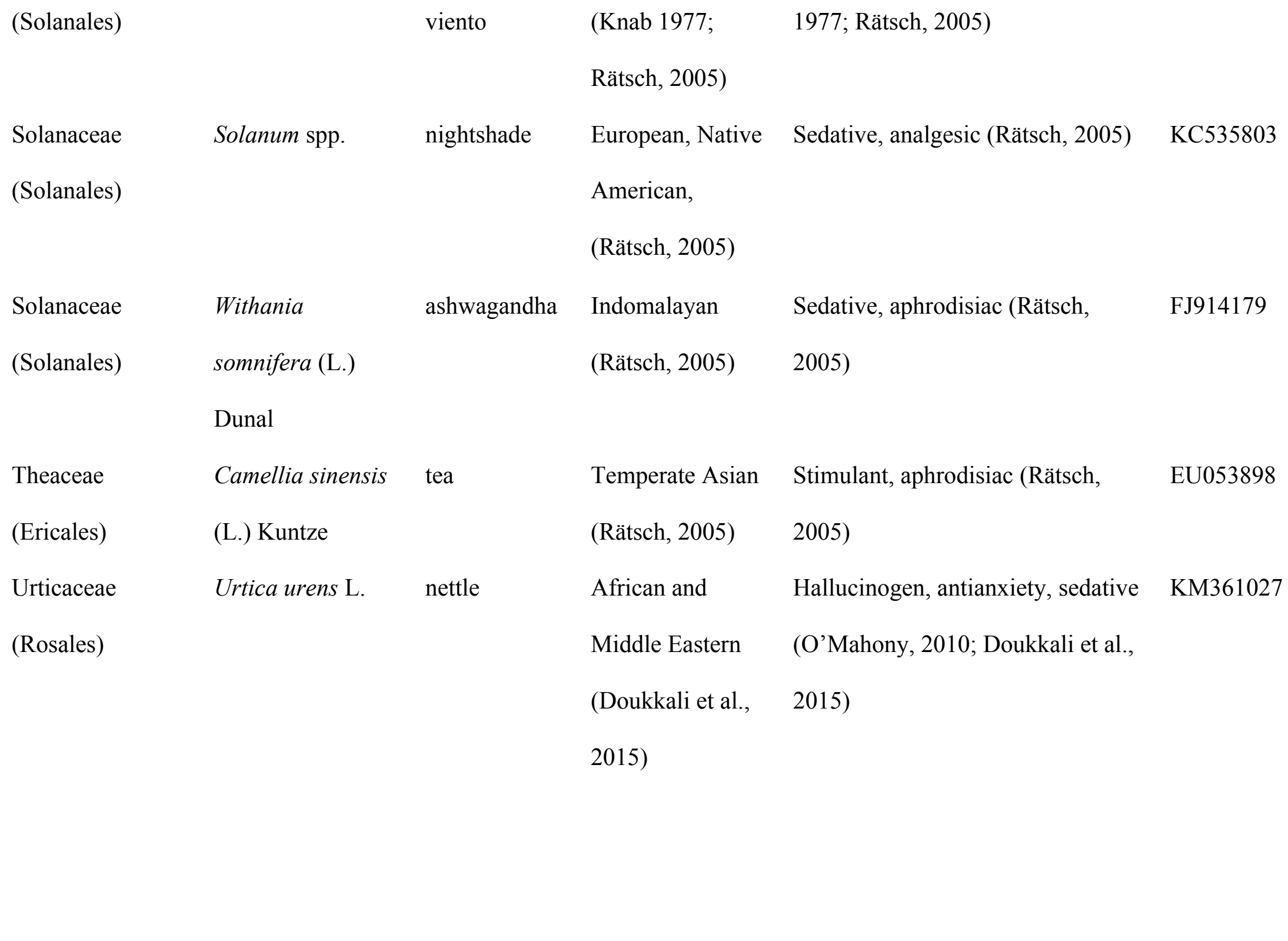


850 Table 2. Main psychoactive families (cf. Fig. 1), their primary psychoactive effect, suspected phytochemical constituents producing

851 the effect, and the primary neurotransmitter (NT) systems potentially affected. "+/_" refers to the activation (receptor agonist) and

852 inhibition (receptor antagonist), respectively, of certain NT receptors by the psychoactive substance.

\begin{tabular}{|c|c|c|c|}
\hline Family & $\begin{array}{l}\text { Main } \\
\text { psychoactive } \\
\text { effect }\end{array}$ & Active phytochemicals & Neurotransmitter systems affected \\
\hline Apocynaceae & Antidepressant & $\begin{array}{l}\text { Indole alkaloids, e.g. ibogaine, } \\
\text { rauwolscine, reserpine, yohimbine } \\
\text { (Spinella 2001; Polya, 2003; Rätsch, } \\
\text { 2005; Pratchayasakul et al. 2008; } \\
\text { Sayin, 2014; Cardoso et al. 2015) }\end{array}$ & $\begin{array}{l}\text { Serotonin (+), dopamine (+), noradrenaline }(+) \\
\text { (Wells, Lopez \& Tanaka, 1999; Spinella, 2001; } \\
\text { Polya, 2003; Grundmann et al. 2007; Arulmozhi et } \\
\text { al., 2012; Zheng, Fan \& Liu, 2013; Sayin, 2014; } \\
\text { Cardoso et al. 2015) [except reserpine but other } \\
\text { indole alkaloids may counteract its effects (Polya, } \\
\text { 2003)] }\end{array}$ \\
\hline Asteraceae & $\begin{array}{l}\text { Hallucinogen, } \\
\text { aphrodisiac }\end{array}$ & $\begin{array}{l}\text { Sesquiterpene lactones (Rätsch, } \\
\text { 2005; Sayin, 2014) }\end{array}$ & $\begin{array}{l}\text { Unknown mechanisms for various sesquiterpene } \\
\text { lactones (Chadwick et al. 2013) }\end{array}$ \\
\hline Cactaceae & hallucinogen & Phenethylamine alkaloids, e.g. & Serotonin $(+)$ (Polya, 2003) \\
\hline
\end{tabular}


hordenine, mescaline, pectenine

(Rätsch, 2005; Sayin, 2014).

Convolvulaceae

hallucinogen

Ergot indole alkaloids (Rätsch, 2005; McClatchey et al., 2009).

Fabaceae

Hallucinogen

Indole alkaloids, e.g. bufotenin,

DMT; tryptamines (Polya, 2003;

Wink, 2003; Halpern, 2004; Rätsch,

2005)

Lamiaceae

Anxiolytic,

sedative,

analgesic
Terpenoids e.g. baicalin, linalool,

labdane, rosmarinic acid, salvinorin

A, wogonin, etc. (Lis-Balchin \&

Hart, 1999; Awad et al, 2003, 2009;

Polya, 2003; Wink, 2003; Heinrich

et al. 2012); leonurine alkaloid

(Rauwald et al., 2015)
Serotonin (+) (Polya, 2003; Kennedy, 2014)

Serotonin (+)

GABA (+) (Awad et al., 2003; 2009; Hajhashemi,

Ghannadi \& Sharif, 2003; Shi et al. 2014;

Rauwald et al., 2015) 


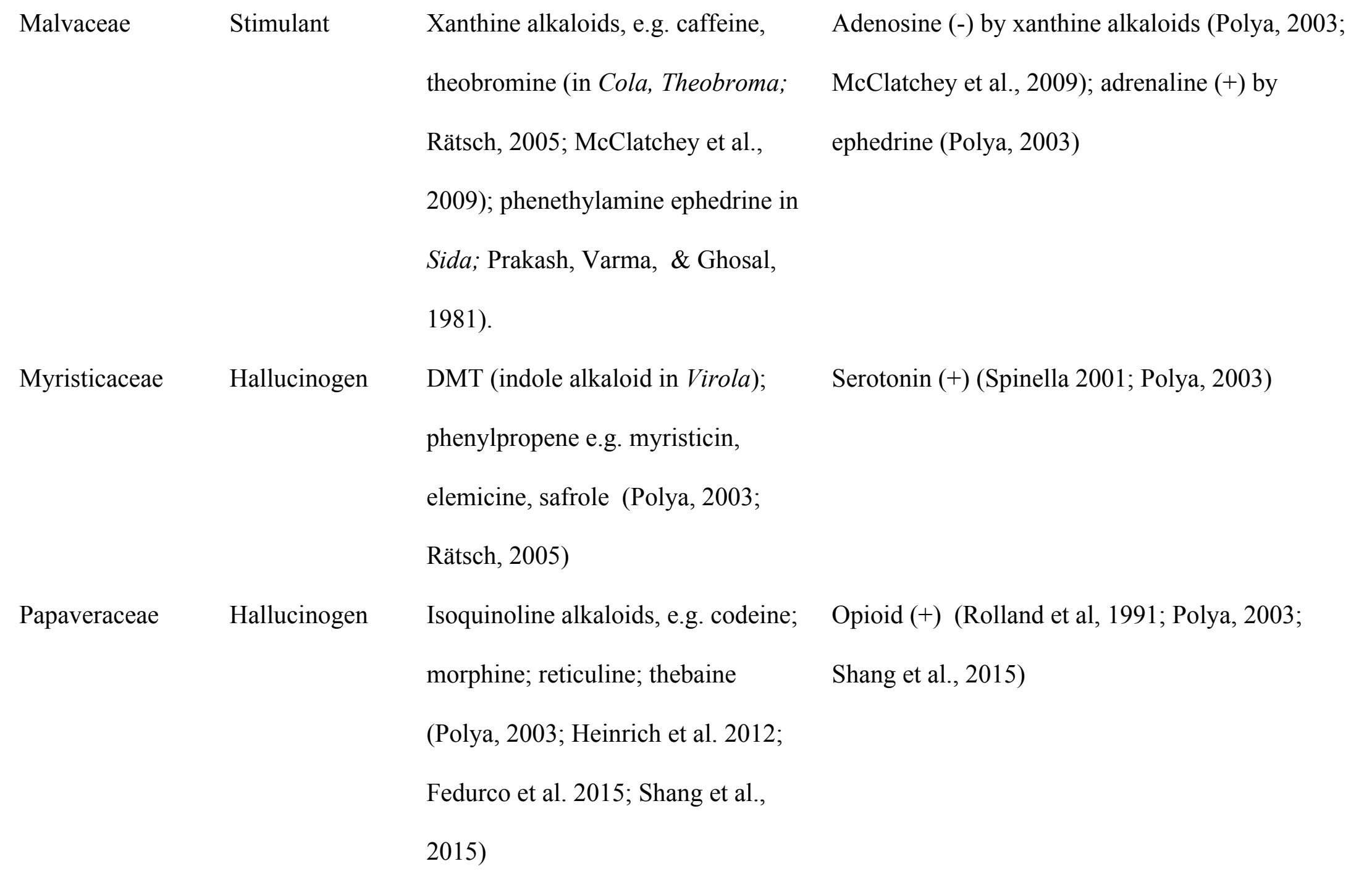




$\begin{array}{lll}\text { Rubiaceae } & \text { caffeine (xanthine alkaloid in } & \text { Adenosine (-) by xanthine alkaloids } \\ & \text { Coffea; Polya, 2003); indole } & \text { McClatchey et al., 2009); adrenal } \\ & \text { alkaloids in others, e.g. } & \text { serotonin (+) by indole alkaloids } \\ & \text { corynanthine, mitragynine, } \\ & \text { yohimbine (indole alkaloid; Polya, } \\ & \text { 2003; Rätsch, 2005; Suhaimi et al. } \\ & \text { 2016) } \\ \text { Hallucinogen, } & \text { Tropane alkaloids, e.g. atropine, } \\ \text { holanaceae } & \text { hyoscyamine, scopolamine (Polya, }\end{array}$

